\title{
Two bullets to the head and an early winter: fate permits Kutuzov to defeat Napoleon at Moscow
}

\author{
Sergiy V. Kushchayev, MD, ${ }^{1,2}$ Evgenii Belykh, MD, ${ }^{1,3}$ Yakiv Fishchenko, MD, ${ }^{4}$ Aliaksei Salei, MD, ${ }^{2}$ \\ Oleg M. Teytelboym, MD, ${ }^{2}$ Leonid Shabaturov, MD, ${ }^{5}$ Mark Cruse, PhD, ${ }^{6}$ and Mark C. Preul, MD ${ }^{1}$ \\ 1Division of Neurological Surgery, Barrow Neurological Institute, St. Joseph's Hospital and Medical Center, Phoenix, Arizona; \\ ${ }^{2}$ Department of Radiology, Mercy Catholic Medical Center, Darby, Pennsylvania; ${ }^{3}$ rkutsk Scientific Center of Surgery and \\ Traumatology, Irkutsk, Russia; ${ }^{2}$ Department of Spinal Surgery, State Institute of Orthopedy and Traumatology, Kiev, Ukraine; \\ ${ }^{5}$ Department of Thoracic Oncology, Petrov Research Institute of Oncology, St. Petersburg, Russia; and ${ }^{6}$ School of International \\ Letters and Cultures, Arizona State University, Tempe, Arizona
}

\begin{abstract}
General Mikhail Kutuzov (circa 1745-1813) brilliantly repelled Napoleon's invasion of Russia. Honored as a national hero and a savior of Russia, Kutuzov has a unique medical story. He was shot in the head twice while fighting the Turks (1774 and 1788) and survived the serious injuries seemingly against all odds. The first bullet "ran through the head from one temple to the other behind both eyes." The second bullet entered the cheek, destroyed upper teeth, traveled through the head, and exited the occiput. Massot, a French surgeon with the Russian army, wrote after treating Kutuzov's seemingly two mortal wounds: "It must be believed that fate appoints Kutuzov to something great, because he was still alive after two injuries, a death sentence by all the rules of medical science." Aided by Massot's expert surgical technique, Kutuzov lived to become intimately engaged in events that altered world history. His health did, however, suffer significant effects due to the bullet wounds. In 1812, as Napoleon's Grande Armée approached, Kutuzov realized he could not confront Napoleon and he strategically retreated from Moscow, submitting the French to the harsh winter and Russian cavalry. Napoleon's devastated army retreated to Paris, and Kutuzov became the personification of Russian spirit and character. Kutuzov's survival of two nearly mortal head wounds created the legends, additional mystery, and drama surrounding him, not the least astonishing of which was the skilled neurosurgical care that probably saved his life.

http://thejns.org/doi/abs/10.3171/2015.3.FOCUS1596
\end{abstract}

KEY WORDS gunshot wound; head injury; history of neurosurgery; Massot; Mikhail Kutuzov; Napoleon Bonaparte; neurological trauma; War of 1812

It must be believed that fate appoints Kutuzov to something great, because he was still alive after two injuries, a death sentence by all the rules of medical science.

-Jean Joseph Xavier Ignace Massot, January 1789 (recorded by F. M. Sinelnikov, $1813,{ }^{42}$ and N. A. Polevoi, $1845^{36}$ )

Mikhail Illarionovich Golenishchev-Kutuzov (1745 or 1747 [accounts of his birth date differ] to 1813) became a Field Marshal of the Russian Empire and is most widely known for brilliantly repelling Napoleon's invasion of Russia in September 1812 (Fig. 1). Each of the five Russian monarchs he served (Elizabeth, Peter III, Catherine II the Great, Paul I, and Alexander I the Blessed) is said to have placed his or her utmost trust in Kutuzov.

For neurosurgeons, Kutuzov's story is unique and informative. He had two serious bullet wounds to his head, and, against all odds, he survived. Kutuzov's impact on the course of world history has become not only legendary, but also equated with the survival of a culture and nation. Through the years, having been recorded in various writings in Russian and French, translations from Russian to French, and second- and third-hand accounts influenced by political, military, and diplomatic intrigue and variations, many details of Kutuzov's injuries have become confused, are unconfirmed, or remain unexplored. Many primary accounts of Kutuzov did not originate with eyewitnesses. In addition there are calendar discrepancies between the Julian and Gregorian systems. We accessed the primary source materials, as well as examined and collated recent information on aspects of Kutuzov and his injuries, to describe the events, historical implications, and neurosurgically related treatments of the time. The details about the surgeon who treated Kutuzov and the surgical

SUBMITTED February 28, 2015. ACCEPTED March 27, 2015

INCLUDE WHEN CITING DOI: 10.3171/2015.3.FOCUS1596.

DISCLOSURE The research for this paper was funded by the Newsome Family Endowed Chair of Neurosurgery Research held by Dr. Preul and by funds from the Barrow Neurological Foundation to Drs. Kushchayev and Belykh. Dr. Belykh is supported by scholarship (SP-156.2013.4) funds from the Council of the President of the Russian Federation for grants in support of young Russian scientists 


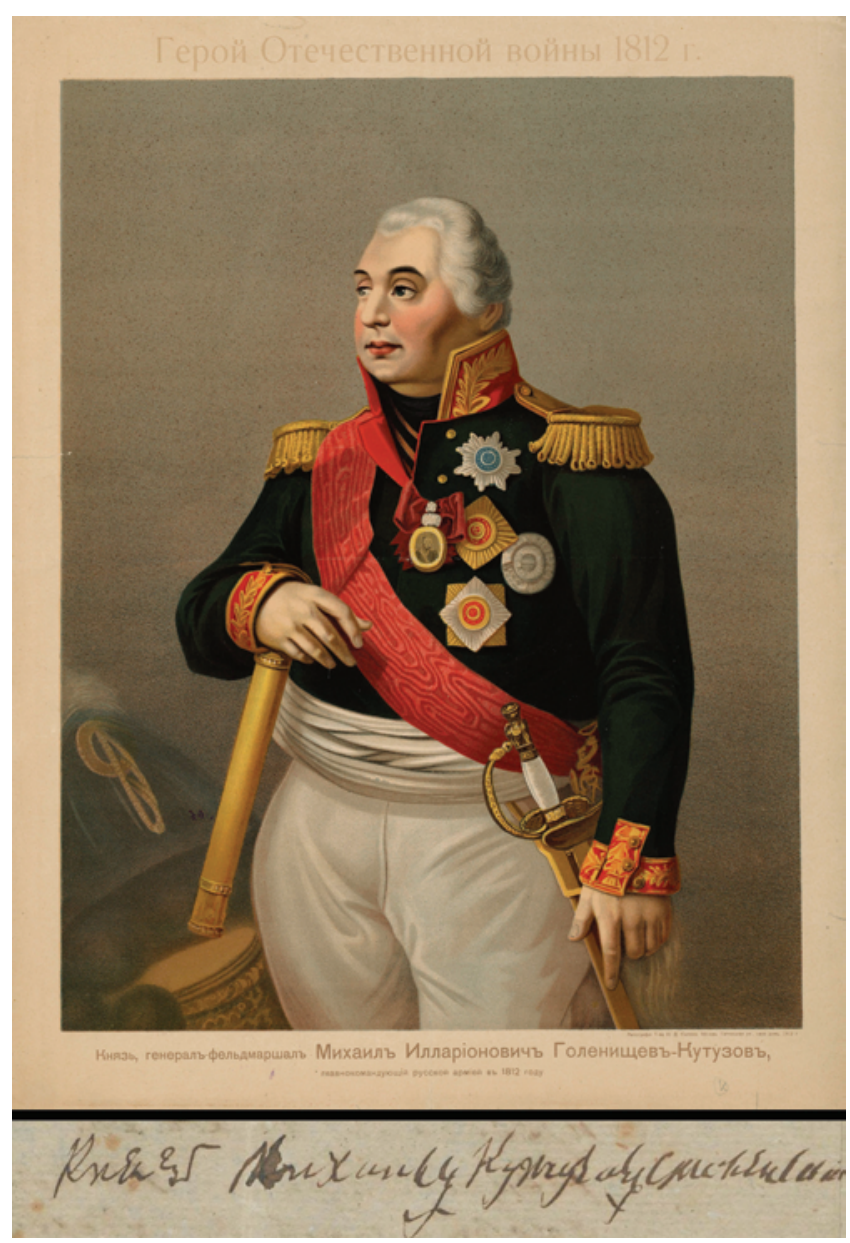

FIG. 1. Upper: Prince, General Field Marshal Mikhail Illarionovich Golenishchev-Kutuzov (1745-1813), lithograph by I. D. Sytin, Moscow, 1912, from the collection of the Russian State Library, Moscow. Lower: Kutuzov's signature. From http://www.1812.rsl.ru/materials/ izoizdaniya/232/?timezone_id=125; figures are considered to be in the public domain.

procedures that likely saved his life have not been previously described or placed in the context of the events of the period. The unsung hero of this saga may in fact be a masterful and trusted French surgeon of the Russian army, about whom we know relatively little, "M. Massot."

Kutuzov was born in St. Petersburg, Russia, on September 5,1745 . His mother died young after giving birth to two other children. His father served in the army of Peter the Great, retiring with the rank of Lieutenant-General, and rose to a prominent position in St. Petersburg society. ${ }^{41,48} \mathrm{He}$ also played a significant role in designing the canal system of St. Petersburg. ${ }^{41}$ Born the son of a general, Mikhail Kutuzov appeared to be destined for a military career. He entered military school at the age of 12 years, and was apparently a brilliant student. Kutuzov's early career showed steady progress. He displayed a proclivity for languages, attaining fluency in English, French, German, Polish, Swedish, Latin, and Turkish.,34,42 After graduating with honors from the Noble Artillery School in 1759, he enlisted in the Engineers Corps and taught mathematics at that school. In 1761, he began a busy period of assign- ments; he was promoted to the rank of ensign and assigned to the Astrakhan Infantry Regiment, which was headed by the renowned Russian commander, Alexander Suvorov. ${ }^{41}$ In 1762, Kutuzov became aide-de-camp to Prince Peter August Friedrich, Duke of Schleswig-Holstein-Sonderburg-Beck, the Governor-General of Reval (now Tallinn), Estonia, and from 1764 to 1765, he was assigned command of troops against Polish confederates. ${ }^{2,20,34,41,48}$ In 1770, Kutuzov received his next assignment to the RussoTurkish War (1768-1774), where he held staff positions in General Pyotr Rumyantsev's army, fighting in Moldova (at that time, a part of Russia).$^{48}$ Energetic, highly motivated, and perhaps with a sense of entitlement, Kutuzov let his sense of humor get the better of him in 1772. After he was caught mimicking his superiors, he was sent to fight as a line officer in the ranks of the Second Crimean Army. ${ }^{48}$

\section{The First Bullet}

On or about July 23 or 24, 1774, while fighting Turkish troops in Shumy (now Kutuzovka, or "Kutuzov-village"), a Crimean village near the town of Alushta, Kutuzov was shot in the head as he was moving his battalion forward. Exhorting his troops onward, he was struck by a rifle bullet as he began to descend into a trench. ${ }^{41}$ Vasiliy Dolgorukov, a commander of Russian Crimean forces, wrote in his report of the battle, "This field officer received a bullet injury, which hit him between the eye and the temple and went away in the same place on the other side of the face." 11,48 And so begins the confusion over Kutuzov's injuries, and his legend. Several reports of this injury may be viewed today with skepticism regarding their accuracy. F. M. Sinelnikov, a Kutuzov contemporaneous biographer and military governor of Kiev at that time, recorded, "The bullet ran through the head from one temple to the other behind both eyes. This dangerous passage of the bullet did not injure his eyes, but one eye [the right] became slightly misaligned." ${ }^{42}$ Later, Louis Alexandre Andrault de Langeron (the Comte de Langeron), then fighting against the Turks with the Russian forces, noted, "He was young when he received this wound and he continued to see perfectly through both eyes, just as before." 7 Still more confusing is an account by Parkinson ${ }^{34}$ originating with the Russian Biographical Dictionary published in 1903. The Russian Biographical Dictionary stated that Kutuzov was injured by a bullet striking the left temple, and flying out near the right eye, as written in a report. Parkinson wrote: "There amidst the ruins of Alushta, Kutuzov fell seriously wounded. A Turkish bullet had struck him in the head, and when the surgeons cleared away the blood they found that the ball had entered his right temple, fortunately at a slight angle, so that it had torn out again near his right eye. The brain seemed to be undamaged, but expectations for Kutuzov's recovery were slender." 34 "He was hit by a bullet which flew through his head behind the eyes. Doctors doomed him for death, but despite their opinion and to their astonishment he began to recover, but was deprived however of his eye." 39 However, it cannot be confirmed if "eye" in the former sentence means vision or physicality of the eye. Yet another account states that Kutuzov, as he stood on a rock over a trench moat at the battlefield, was struck by a bullet 
and knocked into the trench on top of dead soldiers. ${ }^{18} \mathrm{~A}$ November 1775 military report sanctioned by Catherine II, which recommended awards for valor and distinction, describes the battle but does not give details of the injury. ${ }^{11}$

Kutuzov's first brain injury was believed to have been caused by a musket ball (Fig. 2). ${ }^{46}$ Around the period of the battle of Alushta, the smooth-bore rifle used by the Turks had an effective range of 50 yards and an extended range of about 200 yards. However, the type of weapon and bullet used against Kutuzov is not known with certainty. Rifled firearms with an extended range were patented in England in 1636 and were used in some divisions of the Turkish army (originating in France). ${ }^{40,50}$ Fortunately, the bullet that struck Kutuzov could have been from a smaller caliber hunting-type rifle. Kutuzov could not have survived a large bullet or musket ball producing a through-and-through cranial injury from a distance of 200 yards or less using the army musket rifle of 1774. A ballistics assessment ${ }^{30}$ is at odds, however, with the account of Sinelnikov, ${ }^{42}$ which presents the case for decreased effective energy as the bullet struck Kutuzov. In addition, the Turkish troops were located uphill and Kutuzov was descending into the trench, thus the bullet's path was oblique-perhaps entering from the upper left temple and traversing to the lower right temple.

Although the location is not confirmed, it is likely that Kutuzov was operated on in a Russian army campaign hospital near the battlefield. Given the severe head wound with two temporal and/or frontal bone injuries, even if the injury was only one-sided, there was probable severe dural bleeding with cranium disruption. Although not stated in initial reports, later accounts credit the Surgeon Major in Chief of the Russian Army, the Frenchman Massot, as surgeon to Kutuzov. This may be erroneous, however, as Massot is not confirmed to have been in attendance at this battle. Langeron noted that "The surgeon who treated him kept him in a dark room for six weeks, not once allowing the light of day to penetrate [the gloom]." 7,15 Kutuzov survived, although his wound was slow to heal. His right eye became externally deviated, but, rather dubiously, his sight is mentioned as being unimpaired: "After he received this wound, he continued to see perfectly through both eyes, just as before." 7,42 Kutuzov suffered severe headaches, dizziness, and chronic wound weeping, which prevented him from enjoying court balls. ${ }^{34}$ Such a description suggests he suffered from chronic meningitis, possibly secondary to a cerebrospinal fluid leak that developed after his gunshot wound. Because of this, Kutuzov left the army, and many believed he would never return.

Catherine II awarded Kutuzov the Fourth Grade Order of St. George for his gallantry and assigned a considerable sum from the state treasury for his treatment: "We must take care of Kutuzov. He is going to be my great general." ${ }^{11,42}$ (After his injury, Catherine II always referred to him as "my general." ${ }^{\prime 48}$ ) Kutuzov visited medical clinics in Berlin and spent many weeks resting and undergoing eye treatment in Leiden. There, the examining physicians were astonished by his medical history and his survival. Sinelnikov noted that Kutuzov's appearance "forced the physicians in foreign countries to write dissertations [on such a clinical history and presentation]." One of the physicians wrote, "If such case had been brought to us by his-
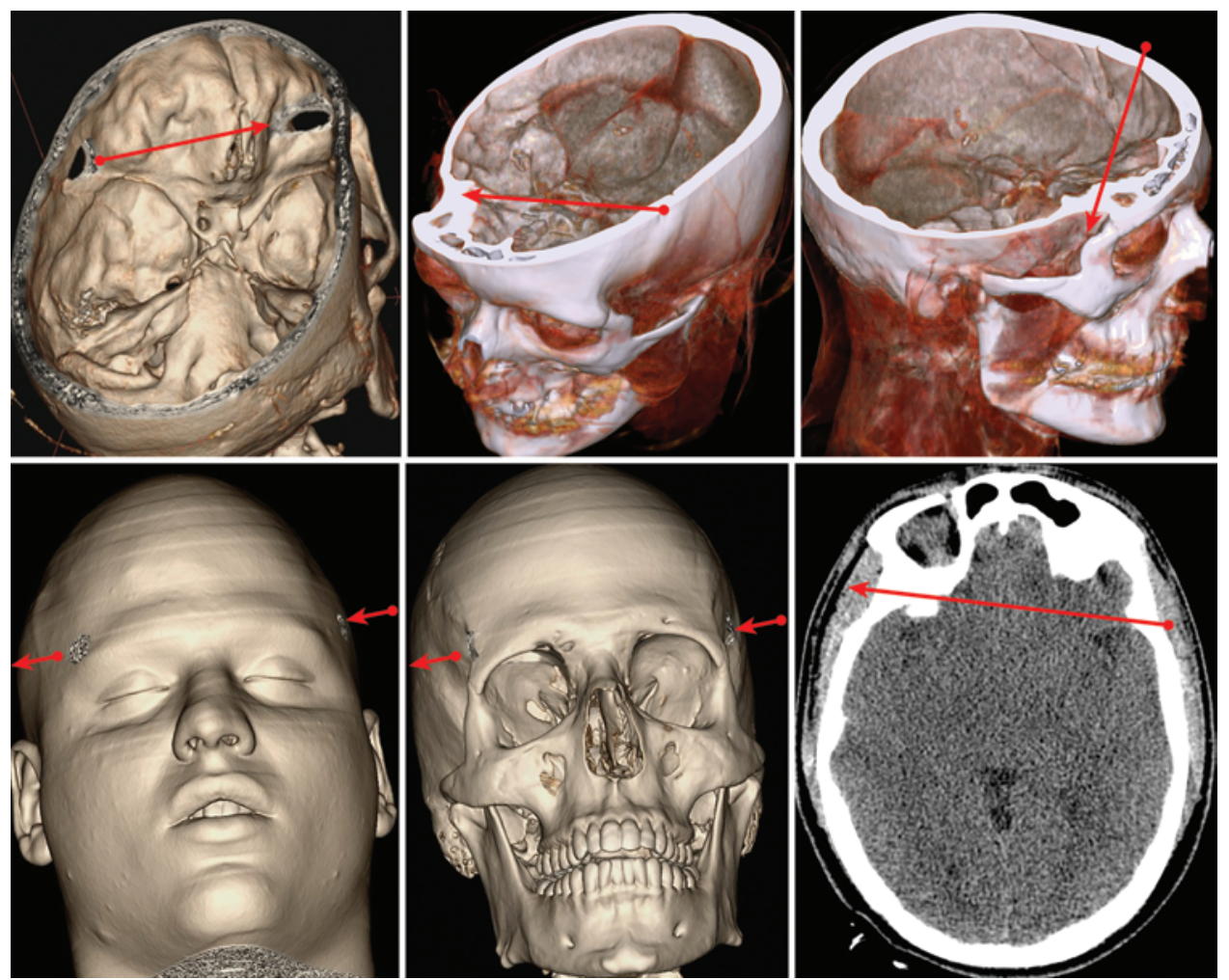

FIG. 2. Reconstruction of the passage of the bullet through Kutuzov's head. 
tory, we would have considered it a fable, but we saw that a miracle had happened with General Kutuzov." ${ }^{2} 2$ While in Holland, Kutuzov learned that one of the professors of medicine, who was loath to believe that anyone could survive such a wound, was scheduled to defend his dissertation. Kutuzov attended this defense at which the professor stated, "I have heard about Kutuzov, but I believe it is a fable because having such wound, it is very difficult to survive and absolutely impossible to preserve sight." Dramatically, Kutuzov stood and replied, "Dear Professor, I am here and can see you"48,51 (Fig. 3).

Kutuzov moved to England, where he studied the organization and military histories of foreign armies, including tracking George Washington's concurrent campaign against the British, concluding that it was not necessary to win battles, but that strategic attrition could win wars. From London, he journeyed to Vienna, and it seems that this 2-year tour was beneficial in terms of health and experience. ${ }^{34}$ Returning to Russia, Kutuzov became a Major General, and in 1778, he married Ekaterina Bibikova, daughter of Lieutenant General Bibikov, a prominent member of Russian nobility. ${ }^{48}$ They had six children; their only son, Nikolai, died of smallpox at about age 2 years, although there were rumors that the child was accidentally smothered by a nurse in his first year. ${ }^{41}$ The Kutuzovs set up their primary home in Ukraine, spending time in St. Petersburg and Moscow, enjoyed activities at the Russian court, and remained in great favor with Catherine II. During a field parade in which Kutuzov was riding an aggressive horse, Catherine II (June 8, 1787) requested that he come over to her. She stated with smile, "I am grateful for you, Mr. General! From this time on I have treated you as among my favorite people and among the most excellent generals. I prohibit you from riding wild horses and I will never forgive you if I heard that you did not follow my order. You should take care of yourself." ${ }^{20,35}$ However, competing interests in the north of the Black Sea were too strong to be quieted by diplomacy, and war with Turkey loomed. Eventually, the Russo-Turkish War of 1787-1791 erupted on August 13, 1787.

\section{The Second Bullet}

Kutuzov's corps was sent to take the Turkish fortress of Özü (referred to in Russian as Ochakov) on the southern Ukrainian Black Sea coast, where Prince Grigori Potemkin commanded the Russian forces along with General Alexander Suvorov. Unlike Suvorov, Potemkin did not believe in pressing the assault and decided to siege the fortress without direct military assault, instead relying on cannon fire. While the Russian army laid siege to the fortress for over 6 months, the generals argued that Potemkin's antistorming strategy was merely a demonstration of cowardice. Although this strategy prevented a great number of Russian soldiers from being injured, many soldiers succumbed to various diseases (Fig. 4).

Military actions were not consistently intensive; however, on August 18, 1788, during one of the Turkish sallies, the Turks counterattacked the chasseurs, and Kutuzov was shot again in the head. ${ }^{4}$ An Austrian diplomat, Prince Charles-Joseph von Ligne, who appears to have been an eyewitness to the event, wrote to Austrian Emperor Joseph II: "The date of 29th August [Julian calendar] not more than forty Turks driving through the sea ascended the cliff and approached to fire from their rifles onto the [Russian] troops where Prince Angalt had exchanged command from Kutuzov. That person who during the last war received a bullet flying through his head behind his eyes, this bullet fortunately did not deprive him of his aforementioned [eyes]. This general received yesterday a second shot in the head, similarly to the [first injury], but above his eyes, and it seems that he would die today or tomorrow. I watched from the beginning of the sortie through an embrasure, and [Kutuzov] wanted to do the same and at that time he was injured. Then [Kutuzov's] chassseurs sought to take revenge for their general without waiting for orders from Prince Angalt, who arrived there, and they rushed to drive away those forty men [Turkish soldiers] who were immediately supported by three hundred [Turkish] soldiers," 8,9 which led to escalation of the battle.

With regard to the second bullet injury, there is again some confusion. The description of its entrance in the cheek with an occipital exit is supported by V. Suvorov's memoirs and Kutuzov's grandson, $\mathrm{Pave}^{44}$ (Tolstoy TMGK: Memories of T.M.G.K. Tolstoy about the Patriotic War of 1812 and the role of M.I.G. Kutuzov. St. Peters-
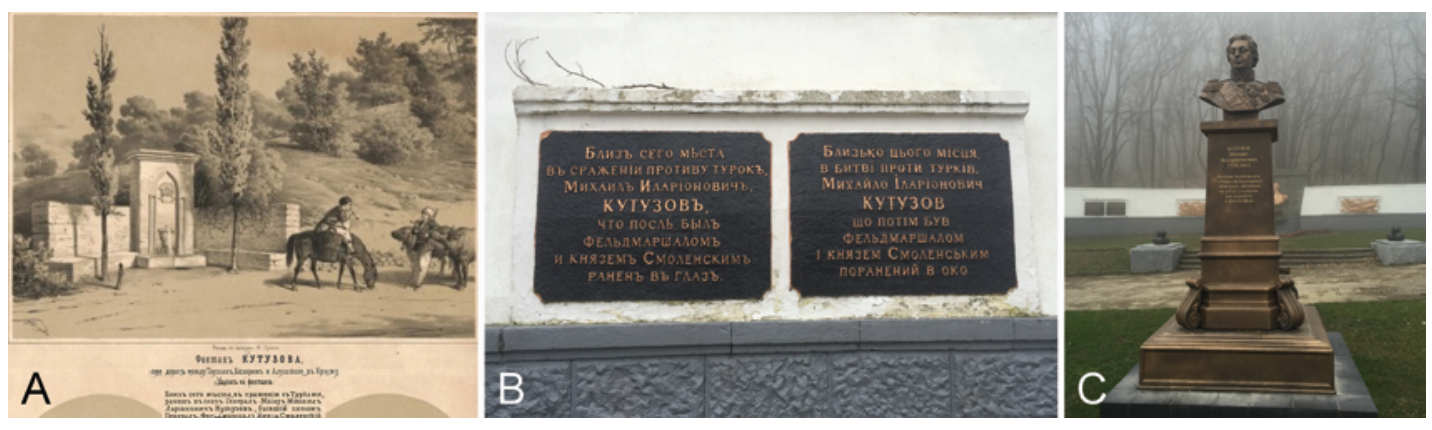

FIG. 3. A: Engraving of a fountain erected as a monument near the place where Kutuzov's first injury occurred, near Alushta, Crimea: The Fountain of Kutuzov Near the Road between Tauchan Bazar and Alushta in Crimea. B: Inscription on a plaque at the location reads simply: "Near this place, in the battle against the Turks, Mikhail Illarionovich Kutuzov, who became Field Marshal and Prince Smolensky later on, was injured in his eye." (Left plaque is written in old Russian; right plaque is in Ukrainian.) C: Present-day photo of the Kutuzov fountain with a bust of Kutuzov erected September 2014. Panel A courtesy of the journal Military Crimea. Panels B and C are the author's photographs taken March 30, 2015, permission granted from Maxim Kvostishkov. 


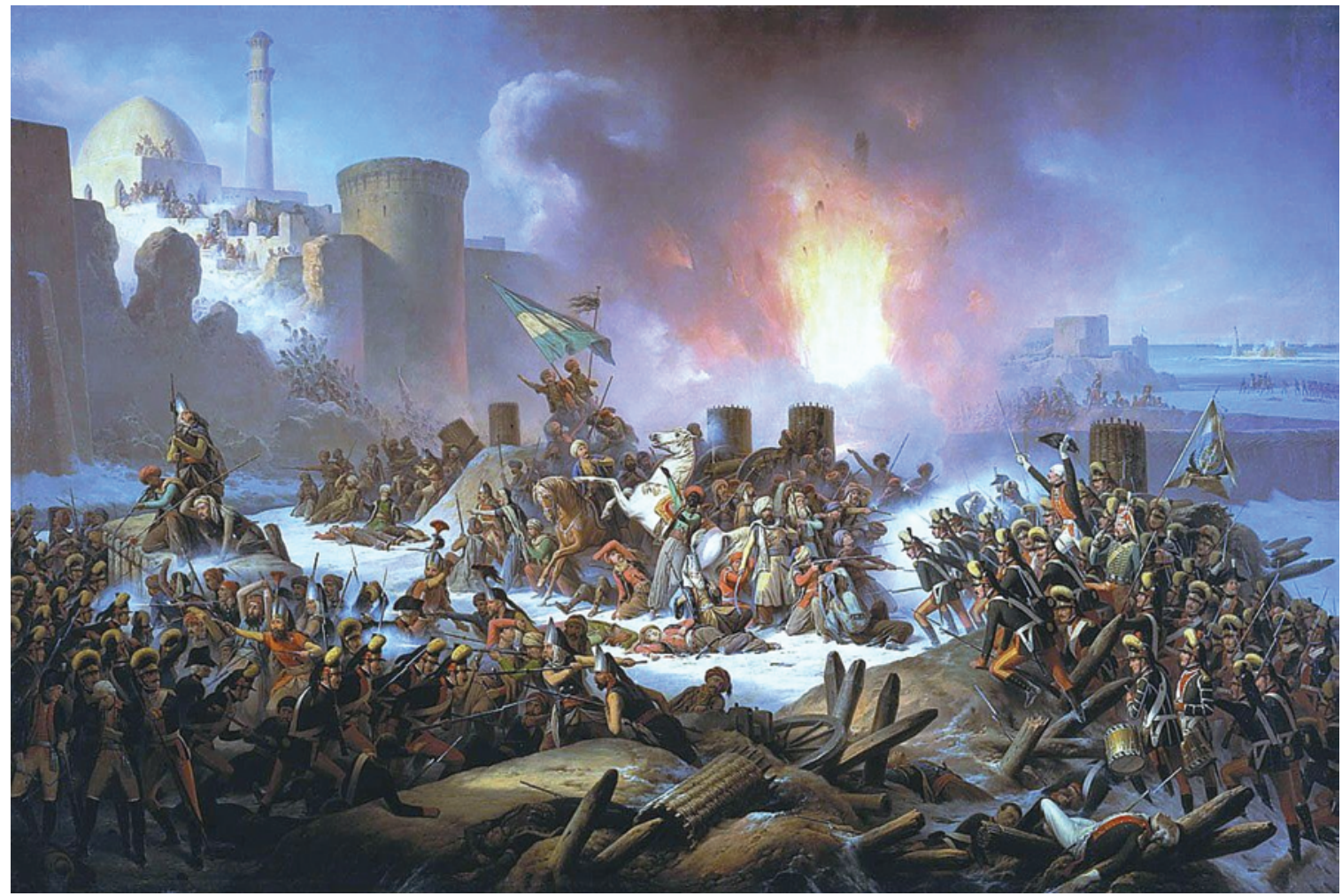

FIG. 4. Victory of Ochakiv, December 17, 1788, by January Suchodolski, painted in 1853. Russian forces are shown attacking the Turkish fortress of Özü. As depicted in the scene, there was apparently massive confusion on the battlefield, likely with bullets flying in all directions. Kutuzov was wounded before the actual main attack on the fortress as Turkish troops landed on the beach and took up hiding positions in the reeds. Throughout the siege, small groups of Turkish troops harassed the Russians. At one point, Russian soldiers washing their clothes in the marshes were attacked, which led to a larger conflagration. From https://ru.wikipedia. org/wiki/Штурм_Очакова\#/media/File:January_Suchodolski_-_Ochakiv_siege.jpg; figure is considered to be in the public domain.

burg: Russian State Historical Archive, 1882, Vol Fond 925, inventory 10). Kutuzov fell, grabbed his head, and inquired why de Ligne had asked him to view above the embrasure at that particular moment. Those around him expected he would immediately die, but after a few minutes, Kutuzov stood up and was involved in the army's maneuvers again. ${ }^{41}$ There was no doctor nearby so Kutuzov continued to give orders; however, due to weakness from blood loss, he was carried out by soldiers from the battlefield and delivered to a military hospital in Ochakov. ${ }^{41,50}$ A version of the injury related by Sinelnikov states that the second bullet injury was similar to the first shot, in that the bullet went from one temple to another behind both eyes, while Parkinson describes that Kutuzov "jerked violently in his saddle and slid from his horse. A musket ball had entered his right temple, in almost exactly the same place as the one 15 years before, and had torn a similar path to erupt beside his right eye. Kutuzov was dragged unconscious from the fight and carried to the surgeons." $16,34,42$

However, this version contradicts surgeon Massot's note to Potemkin, who then appended Massot's report as a separate note to his letter to Catherine II: "His Excellency the Major General Kutuzov was wounded by a musket ball from his left cheek to his back of the neck. Part of the internal angle of the jaw was destroyed. The location of the affected injured parts of the body, close to the organs essential for life, made the general's condition very bad. He was considered to be out of danger only on the seventh day [after injury] and keeps improving., ${ }^{23}$ Catherine II seems to have been especially worried, based on the note from Massot, repeatedly inquiring of Potemkin about Kutuzov's condition: "Describe to me how he is doing and how he was wounded, and order someone go to see him regularly on my behalf" (August 31, 1788); "Order someone go to see him regularly on my behalf, to see how Major General Kutuzov is doing. I am really sorry about his wounds" (September 18, 1788); "Describe to me how he is doing" (November 7, 1788). ${ }^{23}$

It is unknown whether the second injury was from a musket ball or bullet. The bullet's injuring trajectory was level or slightly oblique from the maxillary area (upper point), traversing to the occiput (lower point). ${ }^{41}$ It appears that the distance between Kutuzov and the Turkish troops was approximately 200 yards, which was within the effective range, so that with this shot the bullet had enough energy to pass through the face and skull base (Fig. 5).

Although he recovered from the second head injury quickly and returned to the army within 4 months, $\mathrm{Ku}$ tuzov's right eye deviation and headaches are recorded as becoming worse..$^{20,41}$ Interestingly, in 1792, Catherine II appointed Kutuzov as an ambassador to Turkey, despite 

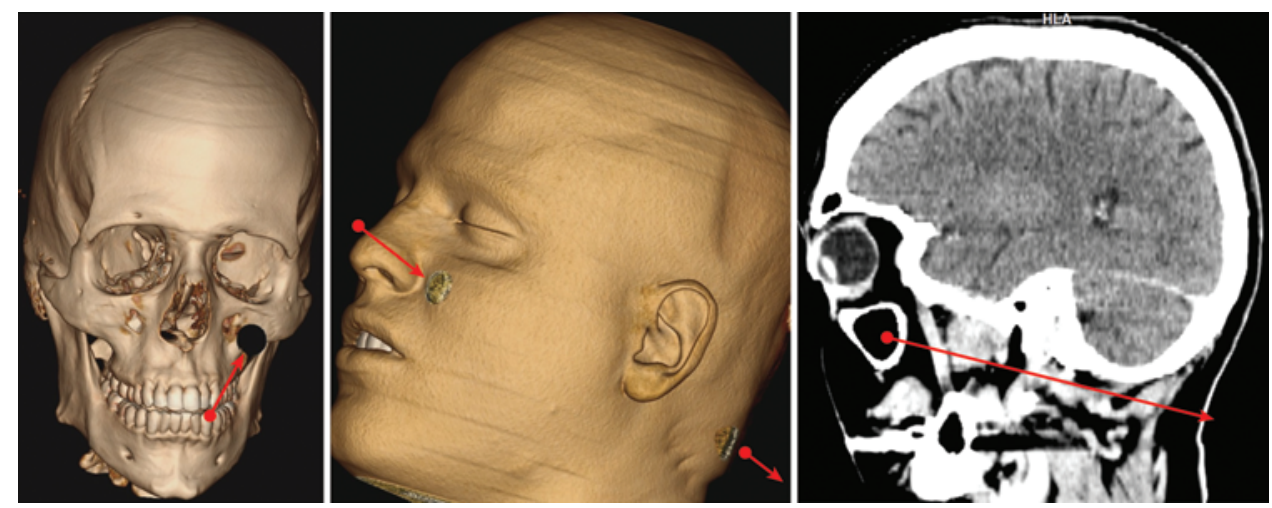

FIG. 5. Reconstruction of the trajectory of the second bullet injury to Kutuzov.

his role in the recent war. Kutuzov was an adept diplomat; he remained in Constantinople for about 12 months and restored satisfactory relations between Turkey and Russia. ${ }^{41}$ During the ensuing years, his vision in his right eye diminished, and he complained of photophobia and increasingly severe ocular pain. ${ }^{34}$ Sinelnikov wrote that "Kutuzov's vision out of his right eye was actually quite good until 1805 . At that time, with the army in Koshov, Hungary, Kutuzov noticed that his eye began to close. Vainly doctors tried to help him, as Kutuzov was not cooperative for taking prescribed medicines. Having read about an eye ointment composition, he called in the doctor and ordered him to prepare such an ointment at once, in spite of the doctor's assurances that this ointment would not only not help his conditions, but would likely be harmful. Kutuzov demanded and although physicians explained to him that he would not be able to see, his request was fulfilled. The next day the doctor, knowing the bad consequences of drug, feared to come to Kutuzov. In the end the physician appeared and stated, 'I have said beforehand that you will not see anything,' Kutuzov replied dispassionately: 'So much the better, I just accelerated that which would over time follow inevitably."'"42

In December 1806, Kutuzov wrote from Kiev, "I am healthy. However, I still have eye pain, as I had before." ${ }^{33}$ During the Battle of Austerlitz, November 20, 1805, Kutuzov received a third head injury, although not serious, as it was to his cheek and likely from shrapnel. He refused help from Alexander I's court physician, and it is reported that the right ptosis worsened after the injury. ${ }^{41}$ Kutuzov expressed his gratitude for the offer, but noted that he did not require help. Pointing to the battlefield, Kutuzov told the physicians that their services were needed much more by the attacking troops. Ultimately, his sight was lost, but the pain disappeared. Advised by his doctors to continue treatments, Kutuzov sought treatment in Hungary (1805), when he noted increased drooping of his right eye.

\section{Clinical and Physical Consequences of the Head Injuries}

If we are to believe that the bullet entered Kutuzov's left temple area, and exited the right, it is likely that the first bullet traversed the frontal lobes, destroyed the orbital roof, injuring the levator palpebrae superioris, caus- ing ptosis, and also injuring the superior oblique muscle, leading to right eye deviation as well as injuring the trigeminal nerve. The second bullet likely did not cause a direct injury to the brain or eye but probably destroyed the internal angle of the mandible. Massot's note is a primary source of information and the most reliable evidence on which we rely for determination of the side and location of the second bullet injury, which recorded it as entering the left cheek. In War and Peace, Leo Tolstoy described the scar from this injury: "Prince Andrew glanced at $\mathrm{Ku}$ tuzov's face only a foot distant from him and involuntarily noticed the carefully washed seams of the scar near his temple, where an Ismail bullet had pierced his skull, and the empty eye socket." ${ }^{47}$ The first bullet probably caused damage to the basal areas of the frontal lobes, resulting in behavioral changes. The second bullet passed extracranially at the skull base, but may have created some temporal lobe effects. Descriptions of Kutuzov after this period include emotional lability and sexual inappropriateness. ${ }^{29}$ Russian General Aleksey Yermolov wrote of the changes in Kutuzov: "Absolutely different personality I have seen in Kutuzov, the person who amazed me during the retreating in Bavaria. Years, severe injury and received insults significantly weakened his mental strength."14 The ophthalmic symptoms reported later in Kutuzov's life were likely those of uveitis (photophobia, a gradual decrease in vision, and severe pain in the eye and head), cataracts, probable secondary glaucoma, and corneal opacity (shown as a depigmented eye in paintings and lithographs), ultimately leading to right-side blindness ${ }^{34}$ (Fig. 6). He may also have had neurotrophic keratopathy. He is reported to have said, "It is better that way, my friend. Since I have no means of saving the eye, of what use was it to me, an old man? Now it will cause me no more hurt." ${ }^{\text {,34 How- }}$ ever, there can be no doubt that these were serious gunshot wounds to the head.

Odd behaviors manifested after the injuries created difficulties between Kutuzov and his contemporaries, such as what seems to be excessive philogyny. Alexander I called him a "single-eyed old satyr." ${ }^{48}$ Perhaps because he was now so put off by Kutuzov's behaviors, Langeron (Fig. 7) provided a vividly detailed assessment:

He would consecrate his evenings to love, or at least his idea of love. These women-such as they were-held over him a 


\section{A}

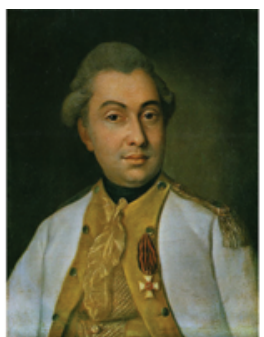

B
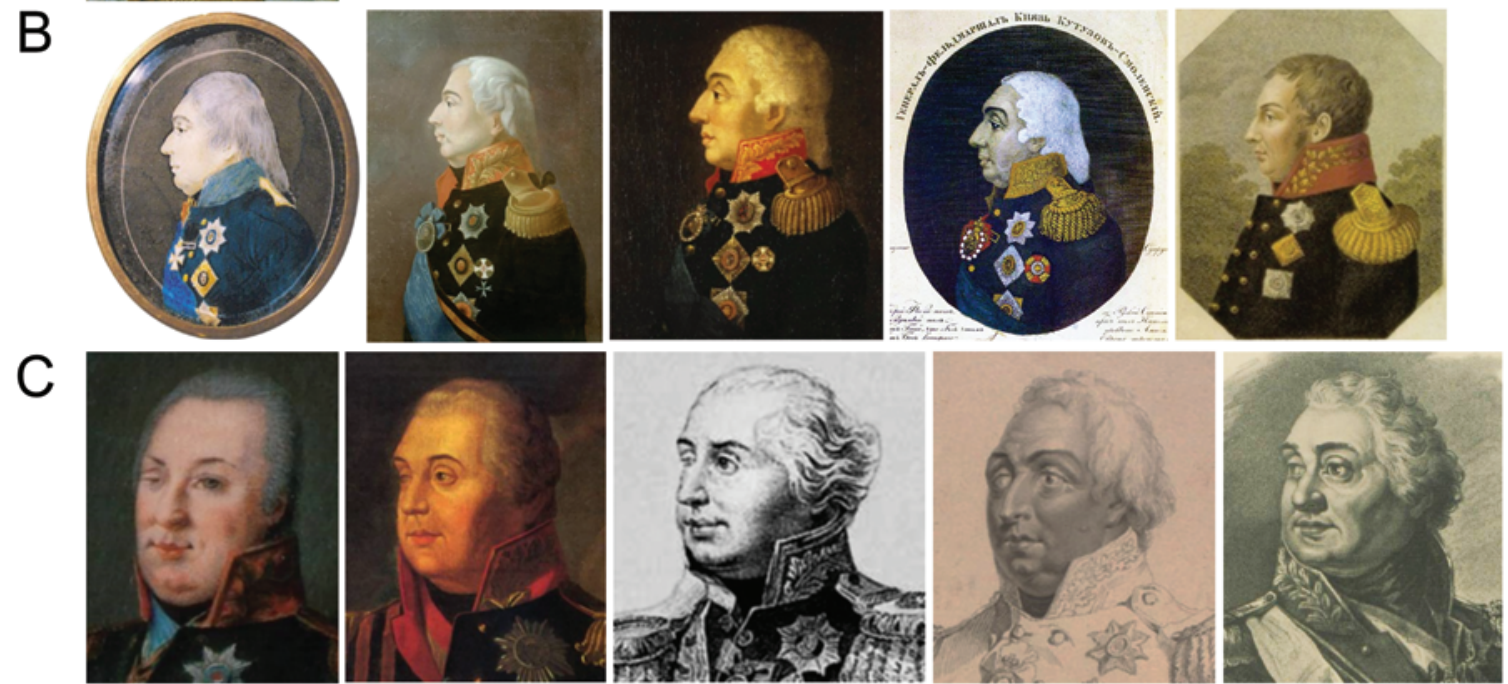

$\mathrm{D}$
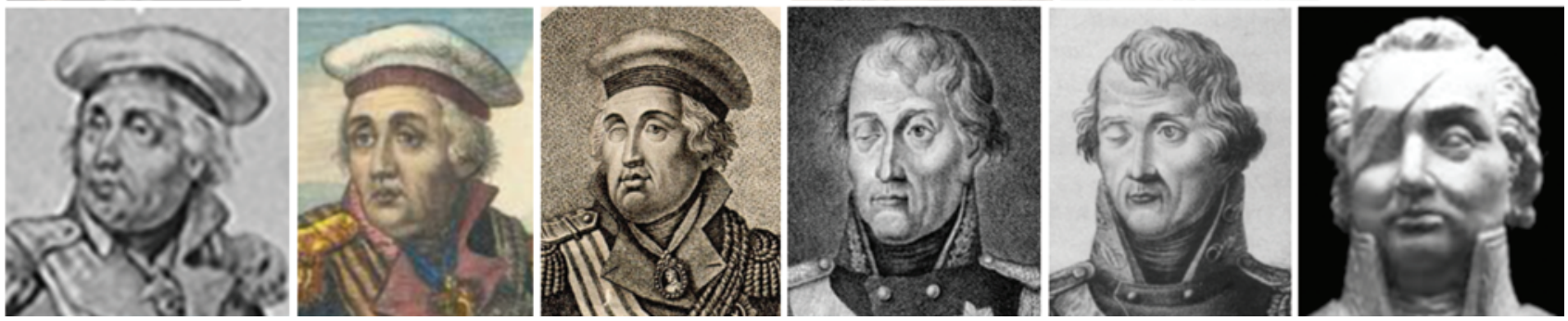

FIG. 6. A: Portrait by an unknown artist of Kutuzov after the first bullet, commissioned by Kutuzov as a wedding present to his wife in 1777. Kutuzov requested that the artist not draw his scars but the effects to the right eye are visible, as well as some fullness and asymmetry of the right face. It is unknown whether this painting accurately reflects injuries. B: Most of the portraits from 1806 to 1812 show Kutuzov from the left side (from left to right: unknown artist, 1810, Hermitage Museum, St. Petersburg; unknown artist, after 1807; S. Cardelli, circa 1810; F. Bollinger from the original painting by M. Smith, circa 1810, State Historical Museum, Moscow). C: Later portraits show Kutuzov in a half-turn to the left. The scars from the injuries and distortions of Kutuzov's head are often only minimally depicted, if at all (from left to right: K. Rozentretter, 1811; M. Volkov, 1813; G. Robinson, 1813; D. Hotwood, 1813; Saint-Aubin Louis, 1813). D: Engravings from original paintings often show interesting variations and assumed progressions of the right eye injury (from left to right: A. Orlovsky, 1812; S. Cardelli, 1813; F. Rosmesler, 1814; unknown German artist, 1813; engraving based on the previous unknown German artist, 1813) and a bandage appears in later works (sculpture by U. Orechov, 1984). Panels A-C are considered to be in the public domain. Panel $D$ is from www.sovet1812.ru/proekt/kutuzov.html.

most absolute and scandalous influence; he himself admitted to me that whilst travelling in Germany during his youth, he was besotted by a German actress whose troupe he followed and for whom he worked as a prompter. Kutuzov was filthy in his tastes, filthy in his habits, filthy in body, and filthy in his business. This female influence over a huge, old, blind man is not simply ridiculous to society, but also dangerous when the individual with such a weakness is employed as commander. He held no secrets to them, he could refuse them nothing, and the inconvenient results of this can be easily imagined....[He] cannot exist without having three to four women around him. ${ }^{7,22}$

Langeron wrote that Kutuzov had a relationship with a 14-year-old married girl during 1811-1812 (although such relationships with young women were not so uncommon or unusual). ${ }^{7}$ Langeron noted:

No-one had more spirit but less character than Kutuzov. Nor could be found in an individual such a combination of address and shrewdness, of so few veritable talents and such immortality. A prodigious memory, highly educated, a rare amiability, pleasing and interesting conversation, good-naturedness (admittedly a little false but warm to those who preferred to be duped by it): such were Kutuzov's charms. Violent, an impropriety akin to that of a peasant when angry or when he deemed that the individual whom he was addressing mattered little, a baseness - often to the point of demeaning - towards individuals he believed to be in favor, an overwhelming lazi- 

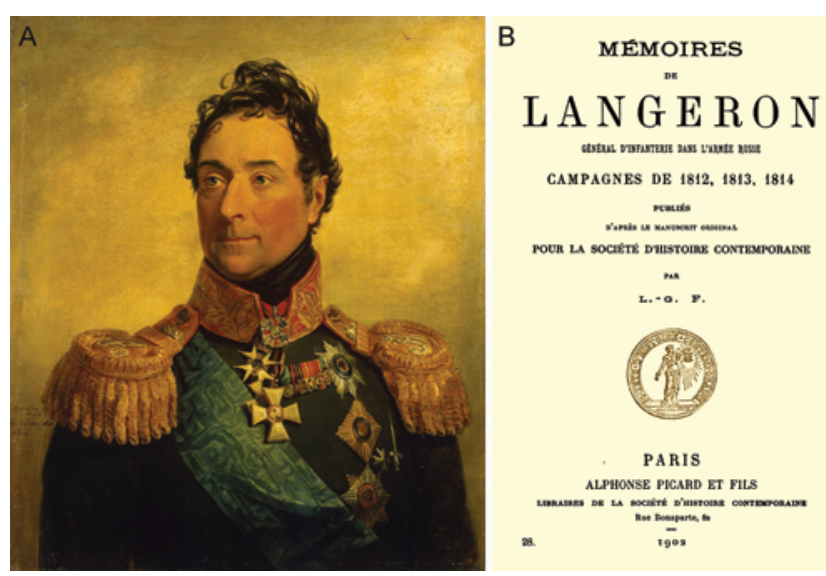

FIG. 7. Portrait of Alexander F. Langeron (1763-1831) by George Dawe (before 1825) (A) and the first page of his Mémoires (B). ${ }^{6}$ While the Mémoires of General Langeron are filled with frank criticism toward Kutuzov, Langeron may not have been unbiased. He was not appointed Russian Army Commander-in-Chief, and Kutuzov refused his suggestion to cross the Danube and attack Rushuk in 1811 during the war with Turkey, as Langeron himself reports. Yet Langeron's description of Kutuzov's behavior corresponds well with the classic presentation of neurological and behavioral changes that are observed in patients after frontal lobe damage. Interestingly, Langeron requested that his Mémoires not be published until 50 years after his death. To this date not all of his Mémoires in Paris are opened to the public; perhaps they still reveal too much about sensitive, yet entertaining, foreign affairs. Panel $A$ is from http://en.wikipedia.org/wiki/Louis_Alexandre_Andrault_de_Langeron\#/ media/File:Langeron_A_F.jpg; Panels $A$ and $B$ are both considered to be in the public domain.

ness, an apathy that dominated everything, a most repulsive selfishness, a libertinism as contemptible as it was disgusting, little discretion when it came to acquiring money: such were the flaws of this same man.

As an officer, Kutuzov was experienced in war, was well-used to it, and was in a position to appraise a campaign strategy and the measures brought before him. He was capable of distinguishing between good advice and bad; he knew how to choose the right argument; he understood the best course of action, but such qualities were paralyzed by indecision, an apathy in mind and body which prevented him from ordering or seeing anything. During battle he would not move, like some immobile mass, except to make the sign of the cross when he heard from far off the whistle of a bullet. He dared not-nor indeed was able - to remedy a thing, nor could he make relevant changes to army positions. He never carried out field reconnaissance himself, never investigated enemy or his own army's positions. I saw him spend three or four months in a camp without ever knowing anything more than his tent or his home. Fat, large, and heavy, he could not rest long in the saddle: fatigue would drain him of his strength. After one hour of exercise - which felt to him like one century - he would be exhausted, unable to entertain any further thought. This same indolence seeped into the affairs of his office: he could not bring himself to pick up a quill. His subordinates, deputies, and secretaries did what they wished with him: and whilst he was surely a greater mind and intellect than them, he was steadfastly unable to review their work, much less direct it or dictate it. He signed everything that they presented before him in order to relieve himself of their presence as quickly as possible. Such matters were accorded little more than briefest of attentions in the course of the morning, most insufficient to deal with the quantity that burdens a general in command of an army. He would rise late, eat excessively, [and] sleep for three hours after dining; he would then require a further two [hours] after that to come to his senses."'

Even during war in 1812 against Napoleon, Kutuzov was accompanied by women..$^{22}$ Everyone knew about the situation, including Alexander I, the Russian ministers, and probably his wife. ${ }^{48}$ In a letter to his wife, Ekaterina, Kutuzov wrote that "Fortuna, that is, a whimsical woman ...will say about him: "there is the old man who always adores our gender, is idolizing it now as well... [and] always pleases women." 48 It seems that Kutuzov's wife, Ekaterina, tolerated his numerous love affairs. ${ }^{34}$ Although possible, the neurological effects are not wholly consistent with classic Klüver-Bucy syndrome, as the temporal lobes were likely not seriously injured. The symptomatology is more consistent with severe frontal lobe injury. It was his psychosexual urges, lack of initiative, passivity, and inattention that became flagrant. Langeron, who may not be unbiased, is still considered one of the best primary, insightful, and detailed sources for the time.

In War and Peace, Tolstoy made Kutuzov a prominent, appealing character. Tolstoy would not have known firsthand of Kutuzov's preinjury personality versus his postinjury manner, as did Langeron. Although Kutuzov was depicted honorably, with a strong devotion to both God and Russia, Tolstoy also included his flaws and weaknesses, stating that he was an old, out-of-shape, tired, easily irritable, and even lazy man. "Kutuzov like all old people did not sleep much at night. He often fell asleep unexpectedly in the daytime, but at night, lying on his bed without undressing, he generally remained awake thinking. So he lay now on his bed, supporting his large, heavy, scarred head on his plump hand, with his one eye open, meditating and peering into the darkness....That morning Kutuzov seemed worn and irritable." ${ }^{47}$ Tolstoy also stressed Kutuzov's sensitivity and emotionality: "What...what they have brought us to!' Kutuzov suddenly cried in an agitated voice, evidently picturing vividly to himself from Prince Andrew's story the condition Russia was in....Taking his hand and drawing him downwards, Kutuzov offered his cheek to be kissed, and again Prince Andrew noticed tears in the old man's eyes." ${ }^{\text {47 }}$

\section{"M. Massot" and Neurosurgery}

Jean Joseph Xavier Ignace Antoine Ehisdore Massot was born to a well-respected doctor's family on July 28, 1754, in Perpignan, a city in southeast France in the Pyrenees region and was educated at the University of Perpignan. ${ }^{6,13,38,53}$ The initial "M." before his last name as displayed on the title pages to his texts, means "Monsieur." Massot received medical training in Paris and at age 27 was an anatomical prosector at the naval hospital in Toulon; he then became the chief surgeon to the French army company under the command of the Marshal de Noailles, Governor of Roussillon. Massot "gained great fame" as a physician and skilled organizer of military medical facilities, so much so that he received substantial recognition and reward from army commanders and the aristocracy. In 1785 Catherine II, who held close interest in the state of 
her army and major projects, and being disappointed with the management of her military medical status, inquired at the French court for an able physician to organize the Russian military medical service hospitals. Massot came "powerfully recommended," arriving in St. Petersburg at age 30, decorated already with the Order of St. Michael. ${ }^{37}$ Immediately Massot impressed the Russian royalty as he challenged the decrepit status of the medical and surgical practices he witnessed, and was named Doctor General of the Russian armies. Massot accompanied Catherine II on various trips, mainly related to military affairs, and was with Potemkin at the siege of Ochakov. Massot was intimately involved in managing the many Russian wounded at Ochakov and other locations, "the Dr. Massot services were increasingly appreciated by Potemkin, who richly paid him, admired his talent, and [Massot] enjoyed the society." On May 1, 1789, Potemkin wrote to Catherine II of Massot's dedicated efforts in Ochakov on behalf of the Russian army: "Doctor of surgery Massot, previously appointed on the French service, at my invitation, and with requesting permission [from his French service], spent all last campaign with the [Russian] army, [which was] graciously entrusted to me. His tireless work and care for the wounded, of whom many were saved from death due to his art, obliges me to humbly ask rewarding him to the rank of court counselor."23

Sometime after Potemkin died, Massot returned to St. Petersburg where he found Catherine II beset with personal problems, and as well the French "colony" of St. Petersburg emigrating back to France because of the growing strife with Russia. Believing that his mission to Russia had been completed, Massot requested of Catherine II that he be allowed also to return to Paris. Apparently Massot carried the great thanks of Catherine II, as "he nobly refused the bonuses offered to him, and carried with him the memories of service and an honorable existence, sometimes with great remorse [for leaving Russia]." Returning, Massot "found Paris in full revolution." Friends in science and medicine wanted him to remain in Paris; however, he refused an appointment in charge of the French army health service and returned to Perpignan, where he also married. Apparently there were some who considered Massot's previous associations in France and his work in Russia traitorous, "a doctor who had been at the forefront in Paris and Russia, [he] hid [as] a dangerous celebrity." After the troubles in Paris, he was again sought for various leading medical positions, being appointed in 1808 by $\mathrm{Na}-$ poleon I as a special medical service and hospital inspector from Bayonne to Perpignan.

Massot was devoted to his family and a beloved Perpignan, "After the events of 1814, he went into the quiet of the civilian life. So...it is appreciated in Perpignan his daily dedication, amenity, the care of his attention, and his devotion for the sick. His kindness, unselfishness delighted [everyone]. Yet the poor did not know that his life had once followed a path of incredible adventure" (Fig. 8). Listed as a correspondent member of the Royal Society of Medicine, Surgery and Pharmacy of Toulouse in 1826, ${ }^{43}$ Massot died 29 March 1837, having one daughter. Besides his texts published in St. Petersburg in 1791 and Paris in 1792, Essai sur les playes des armes à feu (Essay on Wounds

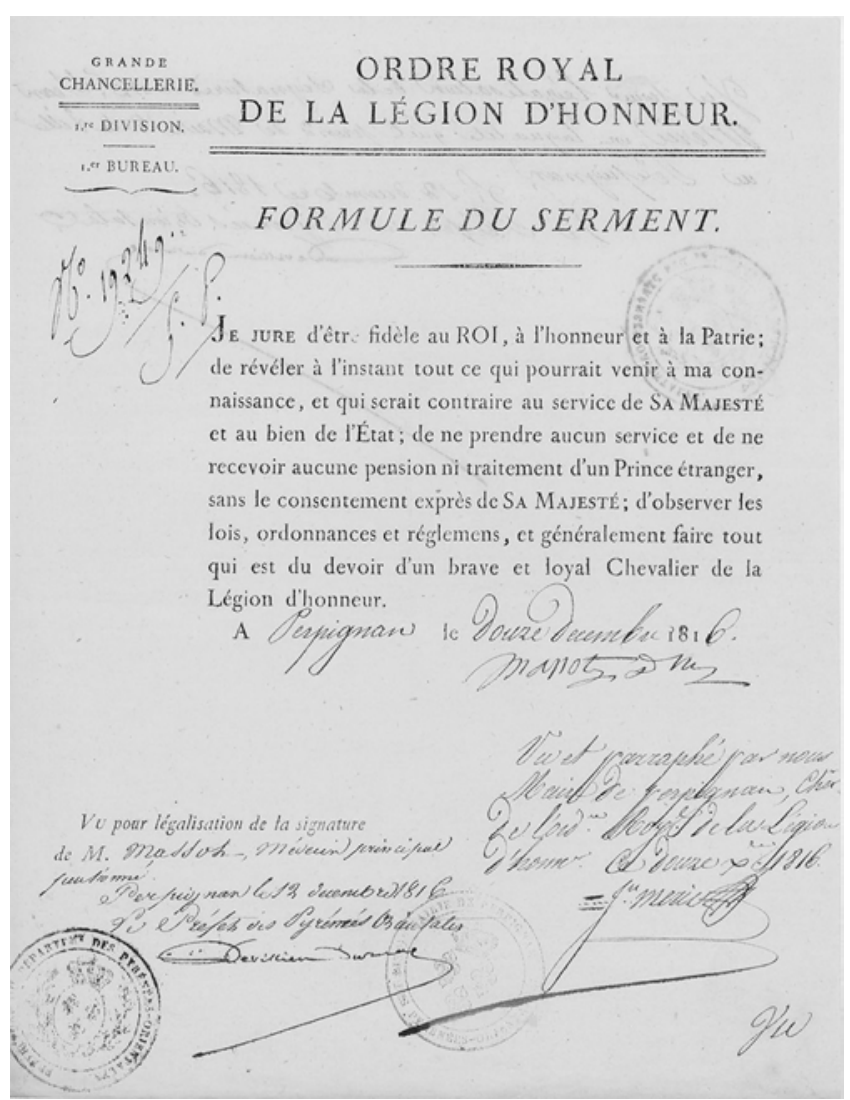

FIG. 8. Oath, signed by Massot, recipient of the Royal Order of the Legion of Honor. Photograph used with permission from the National Archives of France, Paris.

Caused by Firearms) (Fig. 9), he wrote two other excellent works on trauma (war) injuries (Observations sur le danger de différer les dilatations de certaines plaies d'armes à feu; Observation sur un coup de feu qui avait entièrement fracassé la tête de l'humerus). ${ }^{25,26}$

Essentially, the text of the two editions of Essay on Wounds Caused by Firearms is the same; however, the 1792 Paris edition has a better-constructed preface, is a more refined publication, and was republished in 1793 . Massot's text detailed his abilities, keen observations, clinical insights, and effective practical surgical treatments. The surgical procedures described by Massot, his position under Potemkin, and his communications with Catherine II lend credence to the view that Kutuzov was indeed under the knife of one of the most skilled battlefield surgeons of the period, a surgeon trusted and designated by Catherine II to treat the most prominent Russian military figures should they require such.

Potemkin is cited as being responsible for bringing Massot to the war with the Turks at Ochakov and placing him in charge of the campaign infirmaries and was also in the position of court surgeon. Massot is described as being animated, eloquent, outspoken, and zealous. When Massot learned that the plan was to storm the fortress, he assessed the medical status of the Russian army camp. He found deplorable conditions, a lack of medicines, "the surgeons and barbers without instruments, and in the most perfect neg- 


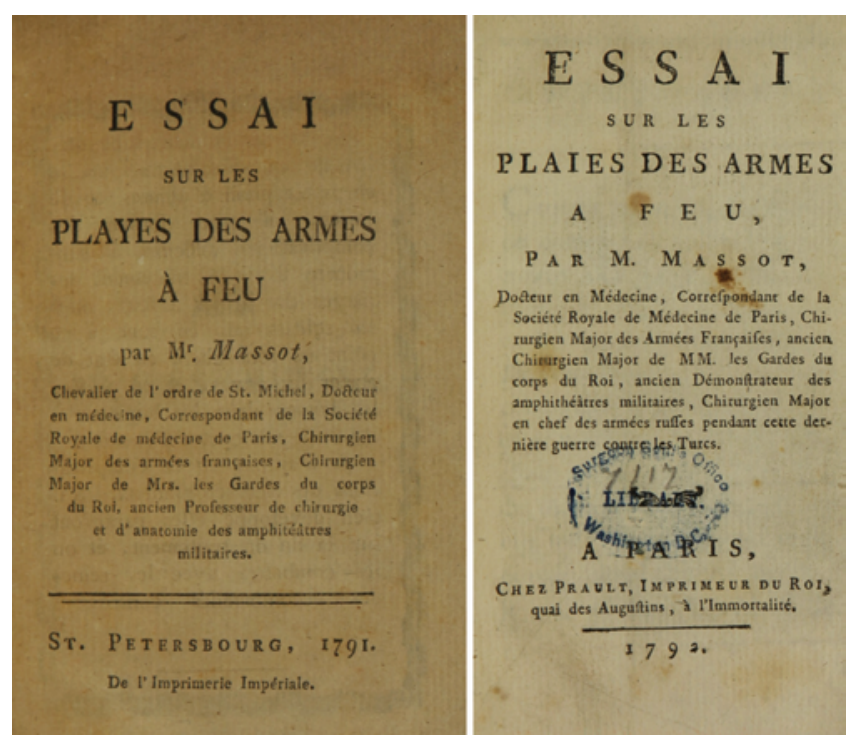

FIG. 9. Title pages from both editions of Massot's book, Essay on Wounds Caused by Firearms, in which he describes injuries caused to the body by firearms and shrapnel as well as treatment techniques. ${ }^{25,26}$ The edition published in Paris is nearly identical to the St. Petersburg edition in terms of information, but it is written in a smoother and more readable style. His title page lists him as Medical Doctor, Correspondent of the Royal Society of Medicine of Paris, Surgeon Major of the French Armies, former Surgeon Major of the King's Guard, former Lecturer at military surgical amphitheaters, [and] Surgeon Major in Chief of the Russian armies during the latest war with the Turks. Figure is considered to be in the public domain.

ligence. They had not even thought of preparing bandages and lint. The surgeons-major, Germans, protected by the court physicians, and jealous of the foreigner, paid no attention to his exhortations, and laughed at his threats." Massot, fearing the potential disastrous consequences, appealed with "an animated and pathetic description of the hospitals" to Potemkin at the dinner table and entreated the prince to procure the necessary supplies. "Prince Potemkin laughed at his zeal and eloquence; told him to make himself easy; that nothing would be wanted, because there would be no wounded. The next day, Potemkin ordered the place to be stormed, and, in less than half an hour, eighteen hundred wounded were heaped up in the barracks and in the streets of the camp. It then became necessary to purchase of the Polish Jews, who followed the army, coarse new cloth, in order to make it into lint. Several thousand soldiers perished in a few days from cold and the consequences of their wounds." 24,52 One can only wonder whether it was on such a day and place that Kutuzov was shot and treated by Massot.

Massot was close to Potemkin and able to speak frankly with him, as the prince used Massot for his French correspondence. Massot's frank relationship with the prince may be the reason he is described as uniting "the position of court surgeon with that of court fool, sometimes carries his license to great length." ${ }^{52}$ However, careful reading of the memoirs indicates that Massot possessed a certain despondent, yet altruistic, opinion toward the wars then ravaging Europe:
He is a Frenchman who does not love France. It appears that he has certain difficulties in connection with the justice of his country, and he has not forgotten them.... the Comte de Segur, who is playing chess with the prince interrupts him [Massot] by suggesting that he might, after saying so much about his old country [France], say something about his new [Russia]. Patiomkin [Potemkin] frowns, but Massot calmly launches out into the most violent diatribes against the ambitious and ruinous enterprises in which Russia has been engaged. He ends with these words: "And do you know why all this ruin is brought about, this bloodshed, this conflict with all Europe? It is to amuse a great prince here present, who bores himself, and to give him the pleasure of adding the Grand Order of St. George to the thirty of forty orders which already cover his chest, and which are not enough for him! $!^{52}$

Although not specified, the location for this episode was likely Ochakov (where interestingly Massot also was in attendance for General Suvorov's injury). Comte de Segur is recorded as bursting out in laughter, while Potemkin hurled the chess board at Massot's head, missing him. Massot was not without influence with the royalty and appears to have carried out actions to improve the status of the local populace as well. A written record exists from Massot in which he directed one of his attendants to take down all the gallows, "and to announce to the inhabitants that in the future they will be expected to carry out their new master's will 'through respect for their duty, and not from fear of punishment." ${ }_{52}$ This likely refers to the inhabitants around Ochakov who had come under Russian rule.

In his essay on war injuries, Massot, in contrast to many medical authors who wrote long, meandering philosophical prefaces, came immediately to his purpose:

Since the practitioners who will read this work might not find it sufficiently full of practical information, I believe that I should inform them of the goal that I had in mind in publishing it. I wanted to write for young surgeons, in order to facilitate their studies by compiling, in the most concise manner possible, all of the knowledge on wounds caused by firearms. I have not read any works on this subject in a very long time; I have not consulted any; I have even tried to forget what I learned from them in my youth. In the nearly twelve years that I have lived amidst armies, I have had much time to reflect on the mechanisms and treatment of these kinds of wounds. The four campaigns that the Russians have recently conducted have considerably increased my observations; these will form a rather voluminous practical collection that I will publish in time. I have focused on the effects of projectiles propelled by gunpowder, and I believed I ought to do so because therapies are always responses to these effects. I do not believe that anyone has read anywhere else observations on gangrene like those to be found in my essay. I would have remained silent if I had not had something new to publish. In the space of ten or twenty years, human knowledge makes noticeable progress. One wishes that every decade the specialists who write to educate others would limit themselves to publishing concisely the discoveries that science has made in that time. I say concisely, because most of them, though they have only one new idea, bore their readers with a mass of citations and lengthy repetitions that one is obliged to read because one is curious to know what these writers want to convey. One should not read my essay if one wants only a simple summary of the teaching of authors who have written on firearm wounds. These are my own, my particular ideas; they are the fruit of my observations and of my practice, which I offer to young army surgeons. ${ }^{26}$ 
A significant portion of Massot's text concerns treatment of head wounds, a frequent injury encountered in war. Because of the nascent rifle technology, velocities of projectiles were not as high as in the modern era, and likely not as damaging; thus, many soldiers initially survived head wounds. He relates his experience with bullets to the head and the clinical course of the patient:

[bullets to the head] also expose the patient to the gravest dangers. It is not rare for serious complications to develop from these lesions, and sometimes even death follows. In the heat of combat, soldiers have been wounded in the head without feeling it; they have later noticed a very superficial bump to which they paid no mind. The fifth or sixth day, the eighth, sometimes even later, they have complained of a heavy feeling in the head, of an uncomfortable and painful circle around the affected area, and of loss of sleep. Other symptoms have appeared quickly thereafter: fever, heat spells, dry skin, excessive thirst, nausea, violent tremors, bizarre behaviors, delirium, and sometimes convulsions. The surgeon, recognizing the source of the problem, made an incision in the affected area, which had grown higher, wider, more painful, and more swollen. The incisions produced bloody pus; the pericranium was detached and as if melted, the bone exposed and altered in its color. In this extremity, trepanning was considered the only option, and the dura mater was found to be inflamed and suppurating. Sometimes such trepanning was successful; but most often it was fruitless. ${ }^{26}$

Massot insisted that the surgeon must be suspicious of the extent of injury and extremely careful with evaluation of the head injury, relating his own direct experiences with injured soldiers:

It can happen that spent bullets striking the skull fracture the external layer of the bone without breaking the skin. It is likely that experienced army surgeons have often treated such fractures without suspecting them, and that they healed their patients simply by insisting on bleedings and the treatments generally recommended for head contusions. These fractures are always without displacement. I will always remember a soldier from the Bouillon regiment at the siege of Mahon. I opened a bloody protrusion the size of a small egg that he had just above the outside of his left eyebrow, a little before the lateral supraorbital area. It was the result of a spent bullet that had struck this spot. The pericranium was detached, and in the center of the exposed bone I found a fracture from which I saw issue a bloody serosity. As the symptoms that had prompted me to open the mass were purely local, I imagined that a shallow trepanning would suffice. Along the length of the fracture I made three holes down to the spongy bone/marrow. About twenty drops of colorless blood issued forth. Two months later I saw this man again. He had had the protrusion surgically removed, and the scar was closing. I have no doubt that in this case the little blood that was outside of the vessels in the diploë/spongy bone would eventually have deformed the inner bone face and led to serious complications. When these kinds of fractures are not diagnosed, the complications that arise from them only appear much later. ${ }^{26}$

Massot also detailed the anatomy and effect upon the cranial bone tables after receiving a gun shot and explained the unique characteristics of damage caused by bullets to the head:

When cannonballs or large fragments of projectiles launched from far away strike a large area of the body, very often the skin and muscles suffer nothing else than severe bruising, while the bones, being less flexible, suffer considerable fractures. When they occur in the head, these fractures may be with or without [bony depression or indriven bone]. Those fractures without crushing show breaks whose number, length, width, shape, and direction vary infinitely. ${ }^{26}$

Massot insisted upon the earliest possible intervention to save the life of the head-injured soldier, considering that aggressive treatment was paramount:

Skull fractures with [depressions/crushing/indriven bone fragments] are easily diagnosed by touch and by the complications that accompany them. These fractures cannot occur without the brain suffering violent trauma, and they are always attended by severe hemorrhaging. The patients are always unconscious; they neither see nor hear; they are cold and almost without a pulse; they are half paralyzed, at least in the extremities opposite the side of the head that has been struck. They bleed from the nose, and sometimes from the ears; and there are those who involuntarily release excrement. The surgeon must hurry to cut open the affected area.

Normally the skin tissue is raised by much internal bleeding. There is no rule to prescribe as to the direction and number of the incisions. The surgeon will act according to the nature of the injury, which he will be careful to diagnose in its entirety. If he finds large fragments buried in the wound, and he is not able to remove them without the trepan, he will apply a crown, two if necessary, on the intact bones surrounding the [impact/depression], and through these holes he will insert the elevator under the depressed fragments, and will raise them by lifting at their centerpoints. At other times, by lifting the mobile and almost detached portions, he will have openings that allow him to insert the elevator and that give the blood free issue. Bleeding of the arms and feet will not be neglected, and the surgeon will apply these bleedings according to the strength of the patient. ${ }^{26}$

Massot related exact instructions with regard to using the trepan to elevate bone fragments. He described his rationale for careful extraction of the bullet from the brain using the most gentle instrument-one's little finger, while not every bullet should be removed to avoid causing additional brain damage:

The extraction of bullets from these fractures is not difficult, provided that the bullets are accessible with surgical instruments. When they have penetrated the brain, they are enveloped by brain tissue which, by folding in on itself, has covered the channel made by the bullet. One will discover where the bullet is lodged by carefully inserting the little finger in the direction of the bullet's path. When one has found the bullet, one withdraws the little finger and inserts the pliers to perform the extraction. If bullets are too deeply lodged in the brain, one leaves them. Drawn-out, forceful, and imprecise probing would be extremely dangerous. It has been said that bullets lodged in the brain are not, by their presence in this organ's substance, an obstacle to recovery. [Footnote: How to imagine that the spongy substance of the brain could tolerate the presence of bullets? It is nevertheless an assertion made by several authors. It is likely that having simply traversed the brain, these bullets lodged themselves in the dense mass at the base of the skull.][sic] $]^{26}$

Massot, as well, provided instructions for surgical management of exit wounds.

For Kutuzov, Massot used his expertise perhaps twice. Massot was intimately familiar with bullet damage to the dura. Massot described dural traction and tenting suture procedures to staunch major vessel bleeding. It may very well have been the following knowledge and procedure that Massot used on Kutuzov: 


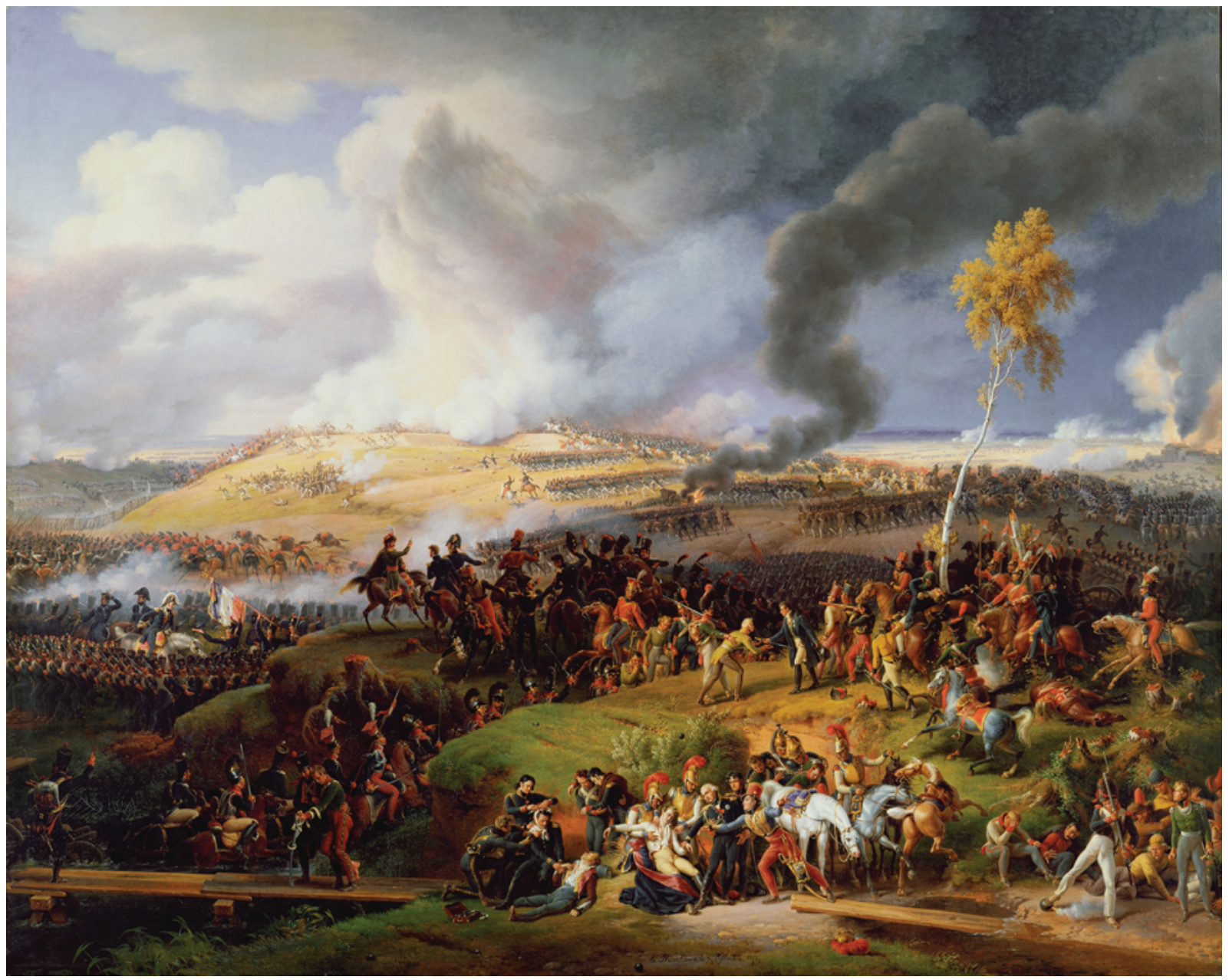

FIG. 10. Battle of Moscow, 7th September 1812 by Louis Lejeune, 1822, Palace of Versailles, France. From http://commons. wikimedia.org/wiki/File:Battle_of_Borodino_1812.png; figure is considered to be in the public domain.

It is rare that wounds made by bullets that penetrate the brain are not complicated by hemorrhaging. The blood flows either from the vessels of the dura mater or from those spread throughout the brain tissue. When the bleeding comes from the vessels of the dura mater, it is advisable to insert between the dura mater and the brain a circular piece of silver in the center of which are two holes placed close together, through which one ties a piece of string. The upper face of this disk is covered with agaric [a styptic compound]. By pulling on the string, one presses the disk firmly against the dura mater, and the bleeding vessel is thus compressed against the skull. This is a useful procedure to know; it can be helpful; but when bullets tear large vessels in the dura mater, they rarely leave the tissues in a state where this method can be easily employed. ${ }^{26}$

Massot was especially concerned about hemorrhage from such patients and likely observed that many of the severely injured patients descended into what we now know as trauma-related coagulopathies, or rehemorrhaging. He advised keeping the patient quiet, while the patient's weakness could also be advantageous for management.

There are brain hemorrhages that are very troubling, and surgery must admit its impotence in these cases. Sometimes they cease when the patient passes out. The scabs that form at such times rarely stay in place, because of the continual movement of the brain. The bleeding reappears as the patient regains his strength, and this repeated loss of blood ends up killing him. The only thing one can do to stop this hemorrhaging is to gently insert pieces of agaric on the surface of the brain, and to apply them with gentle pressure. One applies to the head compresses dipped in cold water and vinegar. One keeps the patient weak, and if one has the luck to stop the bleeding, one will only remove the bandaging at the last possible moment. One bandages the dura mater and the brain with linen strips dipped in Baume de Fioraventi or turpentine oil [both were styptics and astringents]. Sometimes the brain expands through the holes in the bones. If these growths become a problem, they must be removed, and the appearance of new ones must be impeded by means of carefully applied compresses. ${ }^{26}$

Massot, however, ends his section on head wounds as concisely and practically as he began his essay: "Everyone knows that deep wounds to the brain are by definition mortal."'26

\section{War With Napoleon}

Biographers of Kutuzov record Massot stating fittingly and presciently about 4 months after Kutuzov returned to 


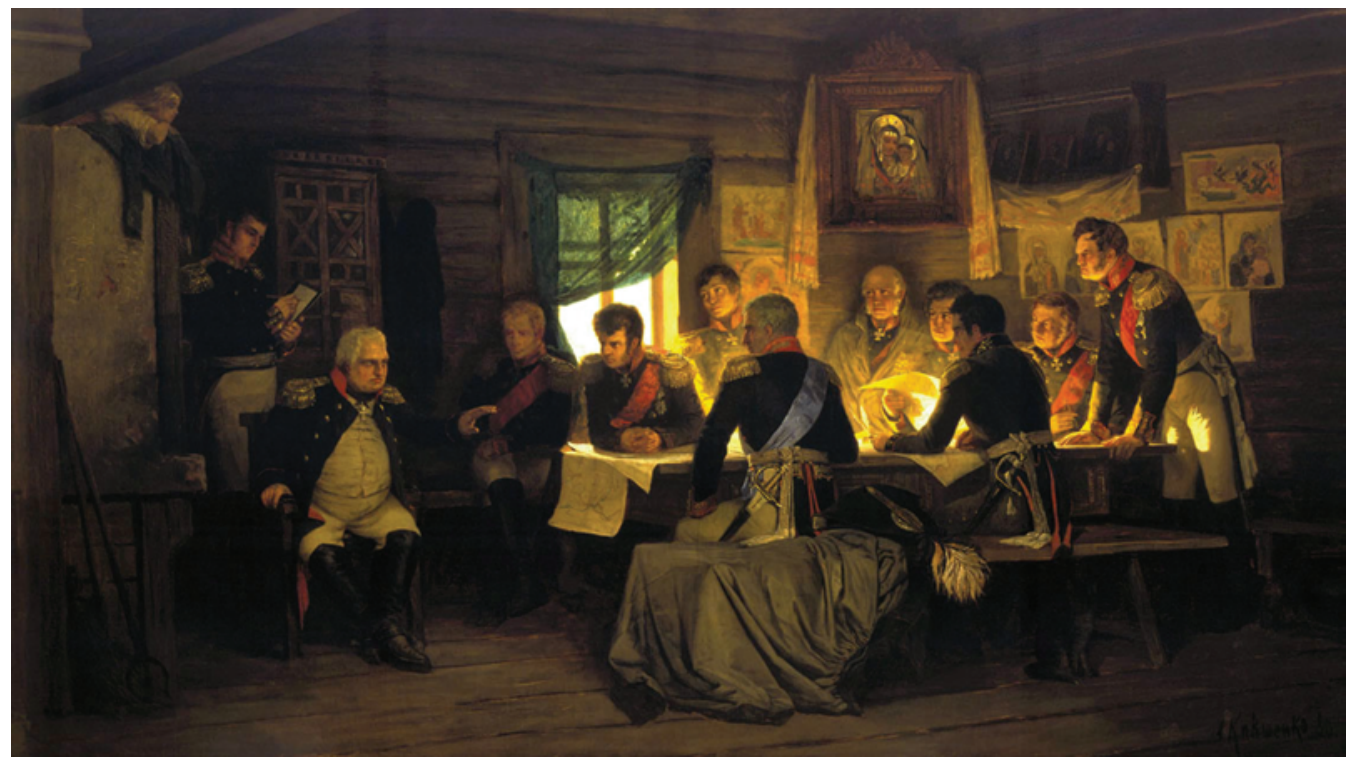

FIG. 11. A. L. Kivshenko's 1871 painting of Kutuzov and other generals deciding to retreat the Russian army from Moscow ahead of Napoleon's invasion, from the collection of the Tretyakov Gallery, Moscow. The meeting was held in a cottage in Fili, which is today in the western section of Moscow. From https://commons.wikimedia.org/wiki/File:Kutuzov_fili.jpg; figure is considered to be in the public domain.

command after his second injury (January 1789): "If we had not been the witnesses...we would have considered the story about Kutuzov's wounds a fairy tale. It must be believed that fate appoints Kutuzov to something great because he was still alive after two injuries that were a death sentence by all the rules of medical science."'t1,42 Indeed, the "something great" was Kutuzov's stand against Napoleon. Kutuzov commanded the Russian army during two major engagements against Napoleon, in 1805 during the Battle of Austerlitz and in 1812 during the Battle of Borodino. Formally, he lost both battles but, ultimately, he won the war, as he had learned from Washington's campaign against the British.

Napoleon took power in 1799 and needed money for his planned military aggressions on both sides of the English Channel. On April 30, 1803, Napoleon sold the Louisiana Territory to the United States for \$15 million, thus financing his military purposes to establish French power on the continent. In 1803, Britain resumed war with France and was later joined by Russia and Austria. In 1805, Alexander I requested Kutuzov to lead Russian forces to help Austria fight off Napoleon's invasion. At the battle of Austerlitz, Kutuzov was the nominal commander of the Russian and Austrian armies; however, both emperors interfered with his command by giving contradictory orders, resulting in a disastrous outcome. Kutuzov, partly blamed for the loss, expressed his displeasure about his commander-inchief's "achievements." During the battle at Austerlitz, Kutuzov also witnessed the death of the husband of one of his daughters. Fedor Glinka described this event to Leo Tolstoy, who later used the story in War and Peace in the episode recounting the wounding of Andrei Bolkonski.. ${ }^{1746}$

In the summer of 1812, with virtually all of continental Europe was under his control, Napoleon marched the Grande Armée into Russia with about 600,000 men and more than 50,000 horses. Appointed on August 20, 1812, by Alexander I to command the Russian Army, Kutuzov realized that he could not defeat Napoleon in direct confrontation. When Kutuzov's daughter asked her father, "Do you really hope to defeat Napoleon?" he answered, "Defeat him? No." Then, he added, "but I hope to deceive him." ${ }^{41}$ Referred to by Napoleon as "The Sly Old Fox of the North," ${ }^{41}$ Kutuzov developed a strategy of wearing down the French with incessant minor engagements while retreating and preserving his own army. Alexander I supported this idea: "I know that the Emperor Napoleon is a great general, but you see I have the advantage of space and time. There is no remote corner of this vast country to which I will not withdraw, no distant part that I will not defend, rather than agree to a shameful peace. I do not attack, but I will not lay down my arms as long as there remains a single foreign soldier in Russia." 49

Throughout his entire military carrier, Kutuzov was well respected for his strategic principles: the avoidance of unnecessary battles, the preservation of his army, reliance upon the power of maneuvers, and an appreciation that psychological victory over the enemy could be equally as devastating as defeat inflicted upon the battlefield itself. ${ }^{17}$ As Russian forces retreated, they burned the countryside behind them, leaving the French with few resources. Before the first battle, 150,000 French soldiers had died. On September 7, 1812, at Borodino, 75 miles west of Moscow, the armies of the Russian and French empires clashed. Borodino became one of the bloodiest battles in history, with 28,000 to 58,000 French and 35,000 to 40,000 Russians dead or wounded (Fig. 10). Although the Russian army retreated, it was a pyrrhic victory for the French. The survival of the Russian army after Borodino was a key factor in Napoleon's eventual defeat and the destruction of the French army in 1812. 

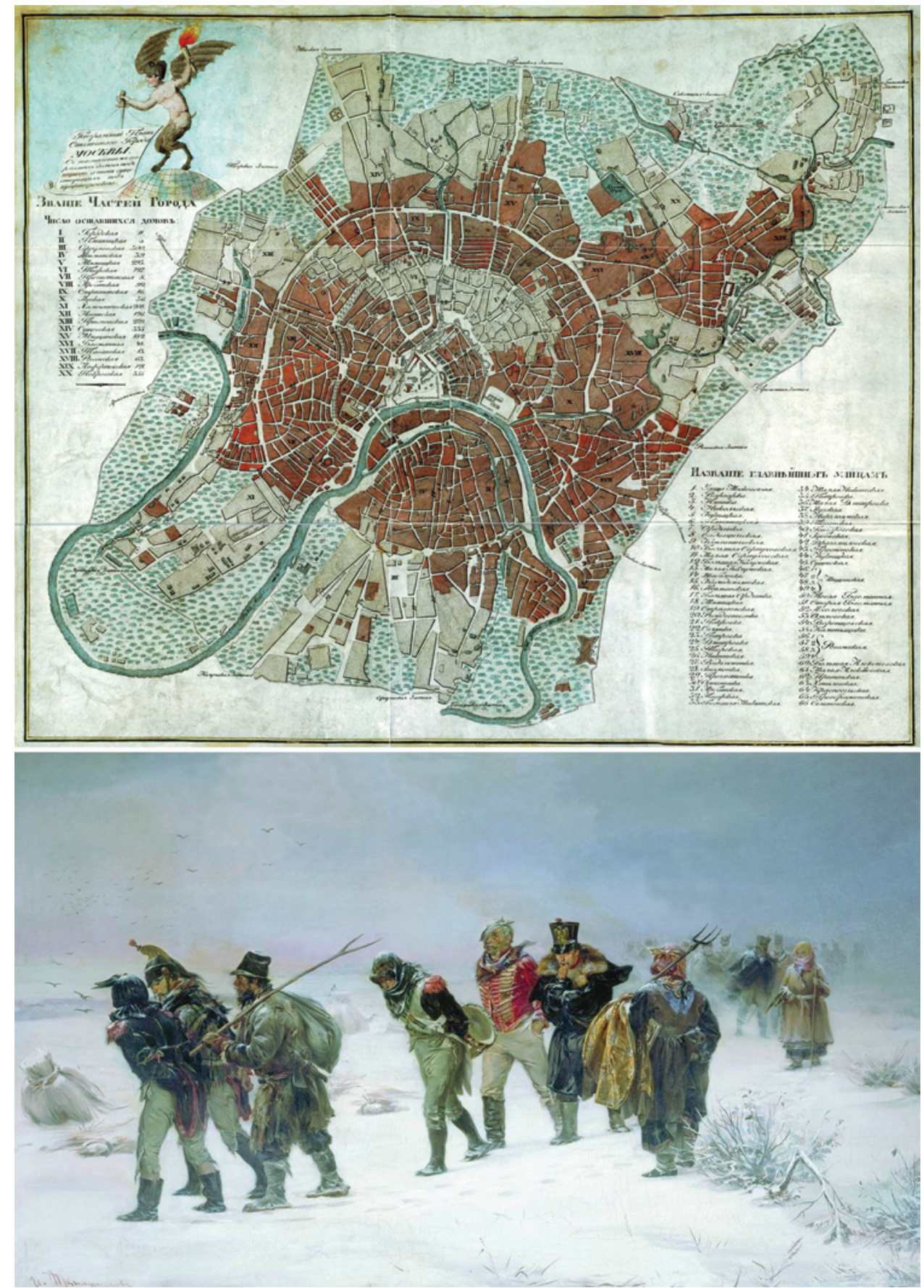

FIG. 12. Upper: An 1813 map of the 1812 fire that ravaged Moscow shows the vast area of destroyed (dark) sections of the city. Key at upper left denotes the number of houses in each part of the city that survived. This image originally appeared as a supplement to the book by A. N. Bulgakov, Russians and Napoleon Bonaparte..., 1813. Lower: One can only imagine the utter despair, hopelessness, and futility of Napoleon's devastated soldiers as they made their way across frozen Russia on their long journey back to France. A lithograph of Illarion Pryanishnikov's popular painting, French Retreat from Russia in 1812 (1873), portrays soldiers of Napoleon's Grande Armée after they had crossed the Berezina River, having been pursued by the Russian and Cossack cavalry and met on the river banks by awaiting Russian infantry. Nearly trapped, the French managed to cross the river, but incurred heavy casualties. As well as having to fight off the Russians, the French were attacked by the cruel Russian winter. French soldiers are pictured wearing anything possible to fend off the wind and cold, including a woman's scarf and Russian uniforms. The French were so devastated and weary that Russian partisan peasants armed with pitchforks and various other farming implements captured the wayward soldiers and returned them to the Russian forces. It may be that Pryanishnikov sought to portray Vasilisa Kozhina's success as the head of her own Russian peasant guerilla force that harassed the French army. Upper panel from https://commons.wikimedia.org/wiki/File:1813_moscow-pozar.jpg. Lower panel from http://commons.wikimedia.org/wiki/ File:French_retreat_in_1812_by_Pryanishnikov.jpg. Both panels are considered to be in the public domain. 
In allowing Moscow to be taken, Kutuzov presumed that the French could not survive the harsh Russian winter: "Napoleon is a torrent which as yet we are unable to stem. Moscow will be the sponge that will suck him dry"4 (Fig. 11). Napoleon entered Moscow on September 14, and found much of the city depopulated and without supplies. The Russians set fires in the city that night, and by the next day, the French lacked shelter as well (Fig. 12 Upper). Fires raged in Moscow for 5 days, after which 12,000 bodies were recovered, although as many as 20,000 people may have perished in the fires, including 2,000 wounded Russian soldiers (with wide variation in reported numbers). Napoleon's army stayed in Moscow only 36 days, suing for peace with Russia. While in Moscow, Napoleon sent General Lauriston to meet with Kutuzov for negotiations. ${ }^{31}$ After a private conversation, Kutuzov declared that he had no power to conclude an armistice and ultimately consented to pass the information in question to St. Petersburg by courier. Kutuzov sent two couriers, one courier to Alexander I with an actual report insisting that he not accept any French proposals and one courier with a "fake" report who was supposed to be caught by the French Army to ensure that they believed Kutuzov to be ready for peace. ${ }^{31} \mathrm{Ku}-$ tuzov deceived Napoleon, believing that "General Frost" would take its toll. Later, Napoleon admitted that not the fires, but the prolonged 5-week stay in an empty Moscow was his major mistake, and he realized that Kutuzov was responsible for this. Kutuzov knew that the infamous, brutal Russian winter was near, and he had tried to waylay the French army as long as he could. Napoleon's Grande Armée left Moscow on October 18-19. Assailed by hunger, the cold (the temperature on October 25, 1812, was $-8^{\circ} \mathrm{F}$, on November 1,1812 , it was $-9^{\circ} \mathrm{F}$ ), and the Russian cavalry, the Grande Armée wasted away (Fig. 12 Lower). ${ }^{45}$ When Napoleon abandoned the army on December 5, arriving in Paris by sleigh, sources state there were only 22,000 survivors of the Russian campaign, and fewer than 10,000 soldiers remained able to fight (with wide variation in casualty statistics). ${ }^{46}$

\section{Kutuzov's Last Days}

During the last years of his life, Kutuzov suffered from rheumatism and knee pain: "he bent onto his knees, grunting from his rheumatism and stayed kneeling on the flag for many minutes." ${ }^{34}$ On April 6, 1813, Kutuzov traveled to Bunzlau (today Boleslawiec, Poland) after meeting with monarchs in Haynau (today Chojnów, Poland). ${ }^{27,34}$ During this trip, the weather suddenly deteriorated, the roads became even boggier, and Kutuzov's carriage became stuck in the mud. Forced to continue on horseback through showers of freezing rain, he became ill and suffered recurrent bouts of fever. ${ }^{27}$ Kutuzov's strength seeped steadily away. Although continuing to command, receive couriers, and correspond with other commanders, he wrote to Alexander I: "I am really in despair because of my long illness and feeling worse from day to day." ${ }^{\prime 8}$ On April 11, Kutuzov dictated a last letter to Doctor Malakhov to be sent to his wife: "For the first time, I am writing to you by another's man hands. It may surprise you that I may be scared for you. I have such a disease that affects the sensitivity

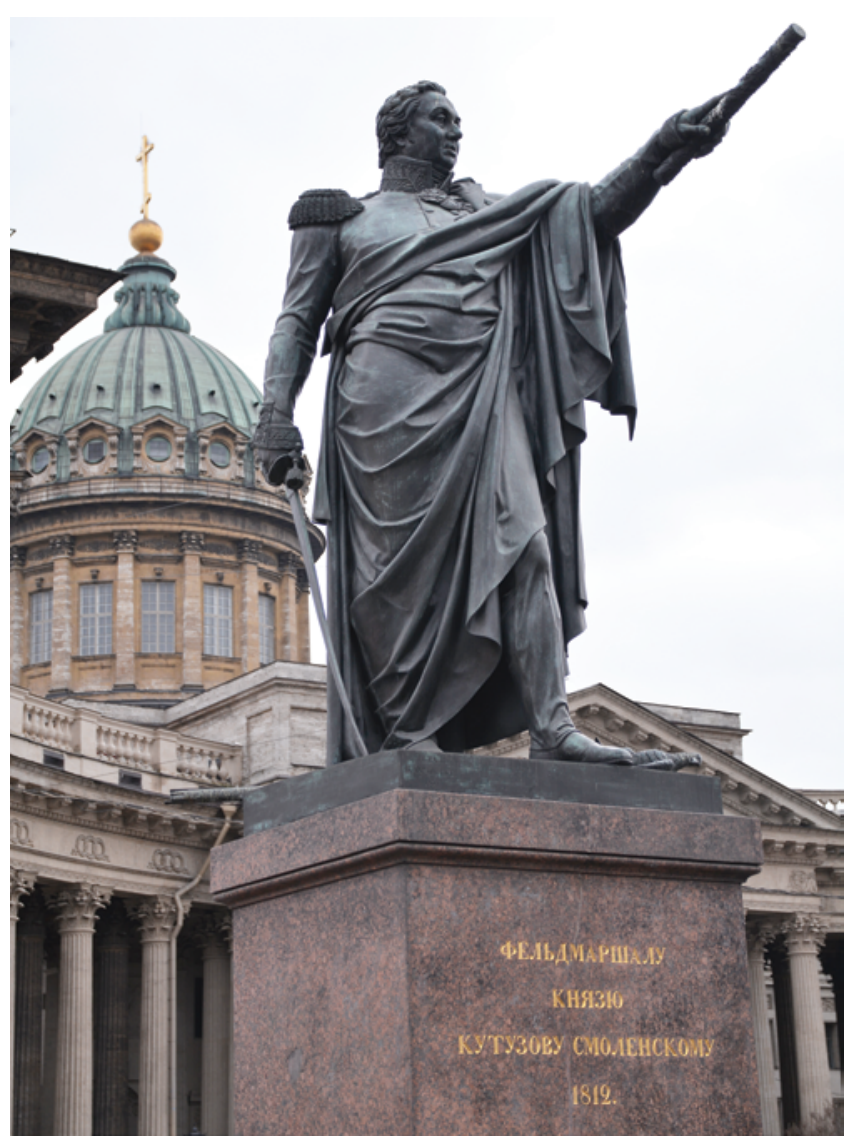

FIG. 13. Monument to Kutuzov outside the Kazan Cathedral in St. Petersburg. Courtesy of Leonid Shabaturov, photograph taken March 1, 2015.

of the right hand and fingers - it [function] is gone...."21 Kutuzov died 5 days later. ${ }^{27,32}$ The news was kept secret for several days for fear of upsetting the Russian army, whose rank and file were fiercely loyal to Kutuzov. ${ }^{34}$ The autopsy performed by a local physician, Vislisenus, concluded the cause of death to be "polyneuritis." ${ }^{27}$ The autopsy revealed an enlarged heart and "internal organs were so distorted that it seemed a miracle he had lived so long." ${ }^{27,34}$ Along with pulmonary and cardiovascular disease, the exploration of Kutuzov's brain revealed to astonished physicians the effects of the devastating injuries. ${ }^{1}$ His embalmed body was transported to St. Petersburg and buried in the Kazan Cathedral. One of the witnesses described the funeral of Kutuzov in a letter:

\footnotetext{
You should have seen this influx of people from the city and surrounding area... despite the insistence of the requests and even the orders of the authorities to drive the hearse by horses, the horses were harnessed only two miles before the city [citizens themselves pushed and pulled the hearse]. Up to Kazan Cathedral, there was no shortage of well-meaning citizens to carry the coffin on their shoulders. The glitter and pomp of the ceremony could not be compared with that pathetic spectacle. ${ }^{12,28}$ (Fig. 13)
}

Mystery surrounds Kutuzov's character after the bullet injuries. Was he the same high-spirited and aggressive soldier as when he was fighting at Alushta and later in 


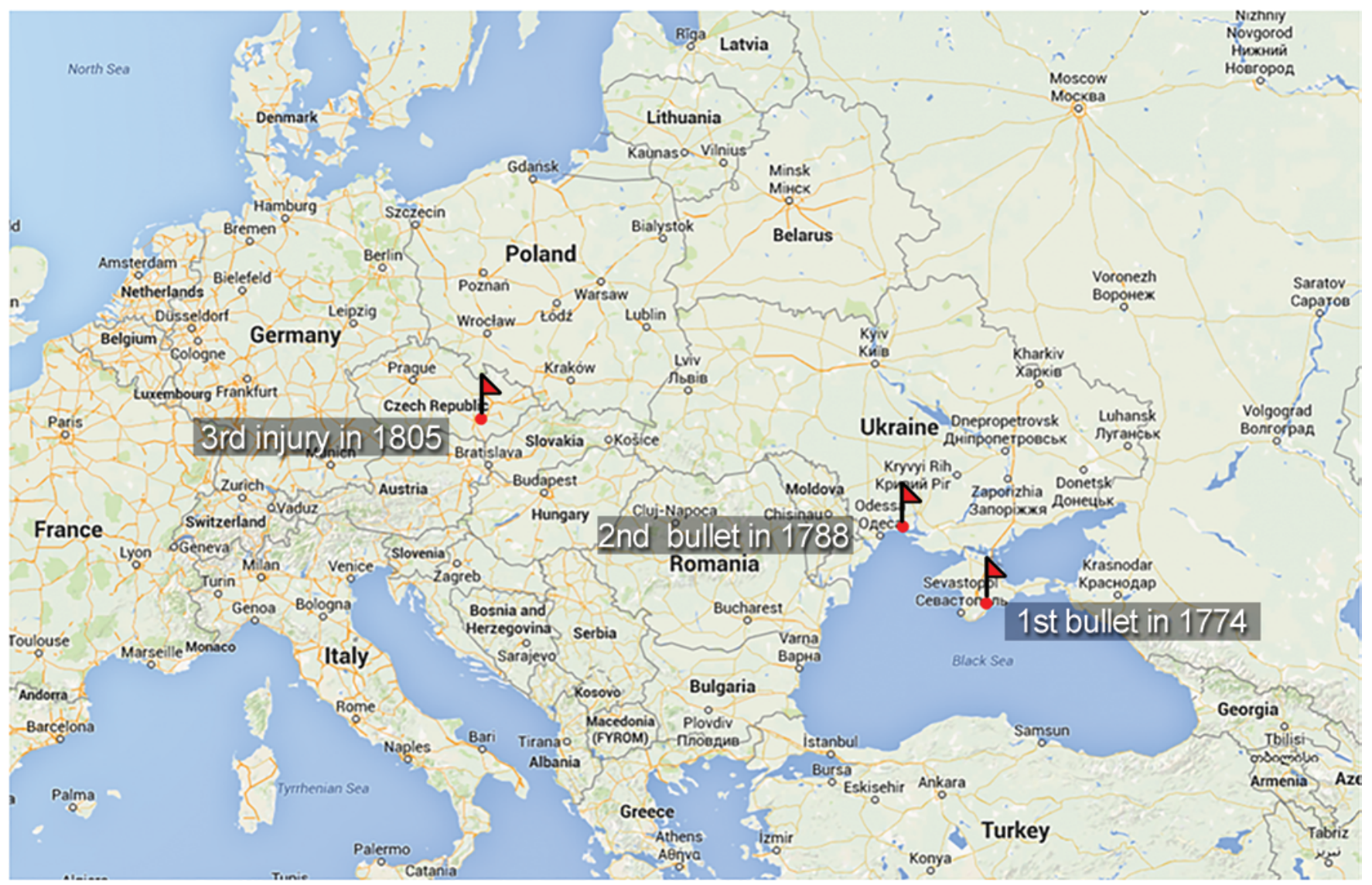

FIG. 14. Contemporary map of Europe with the locations where Kutuzov received his head injuries. He was wounded by the first bullet in Shumy (now Kutuzovka) near Alushta, Crimea. He was wounded by the second bullet during the siege of the Özü fortress near Ochakov, along the southern Ukrainian Black Sea coast. A third minor facial injury occurred during the Austerlitz battle, near what is now Brno, Czech Republic. Map data @2015 Basarsoft, GeoBasis-DE/BKG (@2009), Google, Mapa GISrael, ORION-ME, basado en BCN IGN Espana.

Ochakov, where he led troops in the midst of battle? The accounts of Langeron and others that describe his markedly changed personality and inability to make timely decisions lend support to a significant brain injury etiology. Yet, Alexander I called upon Kutuzov at a crisis to lead the army to defend Russia. Kutuzov's military tactics waged against Napoleon were not the same as he had waged in earlier, younger days. Was that a reflection of military experience, wisdom gained, or was it a consequence of what were surely severe gunshot head injuries (if we are to believe primary sources, the detailed accounts of his surgeon, and the autopsy report) that affected his ability to make decisions? The retreat from Moscow is really one of nonconfrontation, interpreted by some as indecision, yet nevertheless it was a brilliant solution. It is tempting to contemplate that Kutuzov's altered personality may have actually made possible such a situation.

In 1993 Russian neurosurgeons concluded that Kutuzov had suffered double tangential nonpenetrating traumatic brain injuries, without violation of the integrity of dura mater, concussion syndrome, and increased intracranial pressure, although as we have cited there is much confounding evidence..$^{50}$ His body, however, has not been directly examined since his 1813 autopsy. Thus, the details of Kutuzov's cranial injuries will not be settled without such an examination, although perhaps such a story as $\mathrm{Ku}-$ tuzov's is better left with mystery and legend.

\section{Mikhail Kutuzov in Russian-Speaking Culture}

For Russians, Mikhail Kutuzov is honored as among the greatest national heroes, a savior (Fig. 14). Recently, the subject of canonization of Kutuzov was brought forward; however, the Russian Orthodox Church held that such a move was not appropriate because Kutuzov was a Freemason and had an ambiguous personality. ${ }^{5}$ In 1831 the famous Russian poet Alexander Pushkin wrote an elegy, Before the Sacred Tomb, for Kutuzov. ${ }^{10}$ In 1837 another famous Russian poet, Mikhail Lermontov, wrote his famous Borodino to honor Kutuzov, a poem recited by all Russian schoolchildren. ${ }^{19}$ Besides Tolstoy's War and Peace, Kutuzov was a central figure in Sergei Prokofiev's opera, War and Peace, and Tchaikovsky's most important and impressive work, the 1812 Overture, also honors Kutuzov's victory. Although some would say fate allowed the brilliant Russian general, who became the personification of Russian spirit and character, to survive two nearly mortal head wounds, the best neurosurgical technique of the day 
seems to have been overlooked as a considerable part of Kutuzov's success. Indeed, perhaps Massot pronounced his own attachment to the fate of Mikhail Kutuzov-was "the something great," to which fate had appointed Kutuzov, made possible by M. Massot?

\section{Acknowledgments}

We thank staff from Neuroscience Publications at Barrow Neurological Institute for skillful editing and preparation of the paper. We are grateful to Dr. Stephen Greenberg at the US National Library of Medicine History of Medicine Division for expert assistance with archival material. We thank Maxim Kvostishkov for current on-site photography.

\section{References}

1. Balyazin VN: [Unofficial History of Russia.] Moscow: Olma Media Group, 2007 (Russian)

2. Bantysh-Kamensky D: [Biography of Russian Generalissimus and General-Field Marshals.] St. Petersburg: Pushkino, 1840 (Russian)

3. Belov VP: [Humanistic ideas in activity of Field Marshal Kutuzov.] Observer 1:121-127, 2013 (Russian)

4. Bragin M: [Kutuzov.] Moscow: Molodaja Gvardiya, 1970

5. Bykov M: [He doesn't need canonization.] Russian World. (http://www.russkiymir.ru/media/magazines/article/99821/) [Accessed May 19, 2015] (Russian)

6. Capeille J: Dictionnaire de Biographies Roussillonnaises. Perpignan, France: J. Comet, 1914

7. de Langeron AF: Mémoires de Langeron, Général d'Infanterie dans l'Armée russe, Campagnes de 1812, 1813, 1814. Paris: Alphonse Picard et Fils, 1902

8. de Staël-Holstein ALG (ed): [Letters and Thoughts of Marshal Prince de Ligne.] Moscow: University Printing, 1809 (Russian)

9. de Staël-Holstein ALG (ed): Lettres et Pensées du Maréchal Prince de Ligne. London: T. Harper, 1808

10. Dinega AW: Taboo Pushkin: Topics, Texts, Interpretations. Madison, WI: University of Wisconsin Press, 2012

11. Dolgorukov VM: [Communiqué of the Commander in Chief of Crimean Army General in Chief V. M. Dolgorukov to Catherine II about the Battle under Alushta and Injury of M. I. Kutuzov, 28 July 1774], in [Russian Generals.] Moscow: Military Publishing Ministry of the USSR Army Forces, 1950 (Russian)

12. Dzhivelegov AK, Melgunov SP, Picheta VI: [Patriotic War and Russian Society.] (http://www.museum.ru/1812/library/ sitin/book6_02.html) [Accessed May 14, 2015] (Russian)

13. Ecoles spéciales de Médecine de la République française: Dictionnaire des Médecins, Chirurgiens, et Pharmaciens français. Paris: Chez Moreau et Compagnie, 1802

14. Ermolov A: [Notes of Aleksei Petrovich Ermolov.] Moscow: University Publishing 1865

15. Fondation Napoleon: Biographies: Kutuzov, Mikhail Illarionovich Golenishchev. (http://www.napoleon.org/en/reading_room/biographies/files/481511.asp) [Accessed May 14, 2015]

16. Gerhardi W: The Romanovs, Evocation of the Past as a Mirror for the Present. London: Rich and Cowan, 1940

17. Gladkikh PF: [Kutuzov's concern about the health of Russian soldiers (on the 170th anniversary of the battle of Borodino).] Sov Zdravookhr 1983:68-70, 1983 (Russian)

18. Glinka SN: [Russian Anecdotes: Military, Civil, and Historical.] Moscow: University Publishing, 1820 (Russian)

19. Golstein V: Lermontov's Narratives of Heroism. Evanston, IL: Northwestern University Press, 1999

20. Ivchenko L: [Kutuzov.] Moscow: Molodaya Gvardiya, 2012

21. Kutuzov MI: [The letters.] Russian Antiquity 5:698, 1872 (Russian)
22. Langeron AF: [Notes of the Comte de Langeron. The war with Turkey 1806-1812 years.] Russian Antiquity 7:167182,1910

23. Lopatin VS (ed): [Catherine II and G. A. Potemkin. Personal Correspondence (1769-1791).] Moscow: Nauka, 1997 (Russian)

24. Masson CFP: Secret Memoirs of the Court of Petersburg: Particularly Towards the End of the Reign of Catharine II. And the Commencement of That of Paul I. London: Oriental Press, 1802

25. Massot M: Essai sur les Plaies des Armes à feu. St. Petersburg: De l'Imprimerie impériale, 1791

26. Massot M: Essai sur les Plaies des Armes à feu. Paris: Chez Prault, 1792

27. Melentiev VD: [Field Marshals of Victory: Kutuzov and Barklay de Tolly.] St. Petersburg: Piter, 2012 (Russian)

28. Mikhnevich NP: [Russian Army before European campaign], in Dzhivelegov AK, Melgunov SP, Pichet VI (eds): [Patriotic War and Russian Society 1812-1912.] Moscow: Tipographia ID Synina, 1911, pp 23-29

29. Miller BL, Cummings JL, McIntyre H, Ebers G, Grode M: Hypersexuality or altered sexual preference following brain injury. J Neurol Neurosurg Psychiatry 49:867-873, 1986

30. Molin YA, Averkin AV, Alexina LA, Gorshkov AN, Kovalev AV: [Forensic medical and ballistic aspects of gunshot wound to MI Kutuzov in 1788.] Sud Med Ekspert 45:41-46, 2002 (Russian)

31. Neskuchniy sad: [Mission of Loriston.] (http://1812.nsad. ru/125) [Accessed May 14, 2015] (Russian)

32. Noguera-Paláu JJ: [Mikhaíl Ilariónovich Kutúzov (Saint Petersburg, 1745-Bunzlau, 1813).] Arch Soc Esp Oftalmol 86:127-128, 2011 (Span)

33. Opochinin FK, Kutuzov MI: [The letters.] Russian Antiquity $3: 49-60,1871$

34. Parkinson R: The Fox of the North: The Life of Kutuzov, General of War and Peace. New York: David McKay, 1976

35. Petrov MM: [Stories of Colonel Michail Petrov, who served in the 1st Jaeger Regiment, about military service started in 1789, and his life and his three siblings], in Petrov FA (ed): [1812: Memories of the Soldiers of the Russian Army.] Moscow: Mysl, 1991 (Russian)

36. Polevoi NA: [Russian Generals.] St. Petersburg: Konstantin Zhirnakov, 1845 (Russian)

37. Proprietaires de l'Almanach Royal et de la Collection Complete des Lois: Almanach royal, pour l'An M DCCC XXX. Paris: Chez A. Guyot et Scribe, 1830

38. Quérard JM: La France littéraire ou Dictionnaire bibliographique des Savants, Historiens et Gens de Lettres de la France. Paris: Chez Fermin Didot Freres, 1827

39. Russian Imperial Historical Society: Russian Biographical Dictionary. St. Petersburg: Auspices of the Chairman of the Russian Imperial Historical Society, 1903

40. Sakovich VP: [New medical version of M.I. Kutuzov's injury in the Russo-Turkish war (facts, suggestions, analogies).] Neirochirurgiya 3:3-6, 2012

41. Shishov AV: [Unknown Kutuzov. A New Reading of the Biography.] Moscow: Olma-Press, 2001 (Russian)

42. Sinelnikov FM: [Life, Military, and Politcal Accomplishments of His Grace General Field Marshal Prince Mikhail Illarionovich Golenishchev-Kutuzov-Smolensky, etc.] St. Petersburg: Sea Publisher, 1813 (Russian)

43. Société Royale de Médecine Chirurgie et Pharmacie de Toulouse: Séance publique. Toulouse: Imprimerie De JeanMatthieu Douladoure, 1826

44. Suvorov V: His Serene Highness Prince of Smolensk, Field Marshal Mikhail Kutuzov Golenischev-Kutuzov and His Contemporaries. Moscow: I.D. Sytin Partnership, 1896

45. Tarle EB: [Year 1812.] Moscow: USSR Academy of Sciences Publishing, 1959 
46. Tasman W: General Mikhail Kutuzov: one-eyed defender of Moscow. Doc Ophthalmol 98:21-28, 1999

47. Tolstoy L: War and Peace. Madison, WI: Cricket House Books, 2012

48. Troitskiy N: [Field Marshal Kutuzov: Myths and Facts.] Moscow: Centerpoligraph, 2002 (Russian)

49. Tsvetkov S: Aleksandr I. Moscow: Centerpoligraph, 1999

50. Tyurin MV: [On the injuries of MI Kutuzov.] Kalashnikov 3:66-68, 2001 (Russian)

51. Valkovich AMK: Field Marshal Golinischev-KutuzovSmolenskiy: Documents, Diaries, Memories. Moscow: Archaeographic Center, 1995

52. Waliszewski K: The Story of a Throne (Catharine II. of Russia). London: William Heinemann, 1896

53. Wright V, Anceau E, Hazareesingh S: Les Préfets de Gambetta. Paris: Presses de l'Université Paris-Sorbonne, 2007

\section{Author Contributions}

Conception and design: Kushchayev, Belykh, Preul. Acquisition of data: Kushchayev, Belykh, Shabaturov. Analysis and interpretation of data: Kushchayev, Belykh, Shabaturov. Draft- ing the article: Kushchayev, Belykh, Fishchenko, Shabaturov. Critically revising the article: Preul, Kushchayev, Belykh, Fishchenko, Salei, Teytelboym, Cruse. Reviewed submitted version of manuscript: Preul, Kushchayev, Belykh, Fishchenko, Salei, Teytelboym, Cruse. Approved the final version of the manuscript on behalf of all authors: Preul. Administrative/technical/material support: Preul, Kushchayev, Belykh, Shabaturov.

\section{Supplemental Information}

Previous Presentation

This paper was awarded the Vesalius Prize for best resident historical project by the American Association of Neurological Surgeons Section on History of Neurological Surgeons and was presented in part at the Annual Meeting of the AANS in New Orleans, Louisiana, April 28-May 1, 2013.

\section{Correspondence}

Mark C. Preul, c/o Neuroscience Publications, Barrow Neurological Institute, St. Joseph's Hospital and Medical Center, 350 W. Thomas Rd., Phoenix, AZ 85013.email: neuropub@ dignityhealth.org. 